\title{
COVID-19 Hospitalisation in Portugal, the first year: Results from hospital discharge data
}

\author{
Authors: Jỗo F. PEREIRA (D) \\ - Department of Epidemiology, Instituto Nacional de Saúde Dr. Ricardo \\ Jorge, and \\ Department of Mathematics, University of Trás-os-Montes e Alto Douro \\ Portugal \\ (pereira.jpf96@gmail.com) \\ Constantino Caetano \\ - Department of Epidemiology, Instituto Nacional de Saúde Dr. Ricardo \\ Jorge and \\ Center for Computational and Stochastic Mathematics, Instituto Superior \\ Técnico, University of Lisbon \\ Portugal \\ (constantino.caetano@insa-min-saude.pt) \\ LiLiana Antunes \\ - Department of Epidemiology, Instituto Nacional de Saúde Dr. Ricardo \\ Jorge, Lisbon, and \\ CEAUL - Centro de Estatística e Aplicações, Faculdade de Ciências, \\ Universidade de Lisboa \\ Portugal \\ (liliana.antunes@insa-min-saude.pt) \\ Paula Patrício \\ - Center for Mathematics and Applications (CMA), FCT NOVA and \\ Department of Mathematics, FCT NOVA, \\ Quinta da Torre, 2829-516 Caparica, \\ Portugal \\ (pcpr@fct.unl.pt) \\ MARIA LuísA Morgado \\ - Department of Mathematics, University of Trás-os-Montes e Alto Douro, and \\ Center for Computational and Stochastic Mathematics, Instituto Superior \\ Técnico, University of Lisbon \\ Portugal \\ (luisam@utad.pt) \\ Baltazar Nunes \\ - Department of Epidemiology, Instituto Nacional de Saúde Dr. Ricardo \\ Jorge, Lisbon, and \\ Centro de Investigação em Saúde Pública, Escola Nacional \\ de Saúde Pública, Universidade NOVA de Lisboa, Lisbon, Portugal \\ (baltazar.nunes@insa.min-saude.pt)
}

\footnotetext{
*Corresponding author
} 
Received: Month $0000 \quad$ Revised: Month $0000 \quad$ Accepted: Month 0000

Key-Words:

- COVID-19 hospitalisation; data analysis; model parametrisation; statistical distributions.

Using Portuguese diagnosis-related groups (DRGs) data we analysed the dynamics of the COVID-19 hospitalisation in Portugal, with the ultimate goal of estimating parameters to be used in COVID-19 mathematical modelling.

After processing the data, corresponding to the period between March 2020 and the end of March 2021, an exploratory analysis was conducted, in which the length of stay $(\mathrm{LoS})$ in hospital care, the time until death $(\mathrm{TuD})$, the number of admissions and mortality count were estimated and described with respect to the age and gender of the patients, but also by region of admission and evolution over time.

The median and mean of LoS was estimated to be 8 and 12.5 days (IQR:4-15) for nonICU patients and for ICU patients as 18 and 24.3 days (IQR:11-30). The percentage of patients that, during their hospitalisation, required ICU care was determined to be $10.9 \%$. In-hospital mortality of non-ICU patients $(22.6 \%)$ and of ICU patients $(32.8 \%)$ were also calculated. In a visual exploratory analysis we observed that they changed with time, age group, gender and region.

Various univariable probability distributions were fitted to the LoS and TuD data, using maximum likelihood estimation (MLE) but also maximum goodness-of-fit estimation (MGE) to obtain the distribution parameters.

AMS Subject Classification:

- $62-07,62 \mathrm{E} 07,62 \mathrm{~F} 10,62 \mathrm{P} 10$ 
medRxiv preprint doi: https://doi.org/10.1101/2022.03.03.22271349; this version posted March 6, 2022. The copyright holder for this preprint (which was not certified by peer review) is the author/funder, who has granted medRxiv a license to display the preprint in perpetuity.

It is made available under a CC-BY-NC 4.0 International license .

\section{INTRODUCTION}

In Portugal, the first case of COVID-19 was reported on March 2nd, 2020. On March 12, 2020 the Portuguese government declared the State of Emergency, and lockdown measures were implemented to stop the rapid increase of infections. From then onwards, several periods of confinement were implemented, according to the rise and fall in the number of cases and other epidemiological factors [2, 6].

Mathematical models are a suitable tool to develop scenarios to evaluate the impact of different control measures. For COVID-19, several mathematical models have been developed (see [11] and the references therein). The success of these models in capturing the transmission dynamics strongly depend on a good parametrisation. While it is expected that disease and biological parameters do not differ among different regions, other, as demographic and social related parameters, strongly depend on the population under study. Furthermore, there was a necessity for models to consider the hospitalisation dynamics of COVID19 , in order to assess health care burden. To this end, we analysed Portuguese DRG (diagnosis-related group) data with two main goals: to characterise hospital admissions and to estimate suitable parameters of interest.

In Portugal, the clinical data of hospitalized patients is logged according to the International Classification of Diseases, Clinical Modification and International Classification of Diseases, Tenth Revision Procedure Coding System (ICD10-CM/PCS), in line with the 2020/2021 normative [3]. This unstructured data is then grouped into DRGs, with the objective of being used in healthcare management, pricing and decision-making by the hospital management and health professionals, but also by authorized national agencies that use it to perform various types of public health studies and statistical analysis on hospital treatment. The DRG system currently in use in Portugal is the all-patient refined diagnosis-related groups (hereafter APR-DRG) (Administração Central do Sistema de Saúde 2014). This system assigns codes to the patient which refers to a specific diagnosis, so that patients with similar resource usage and costs are clustered. According to Julio Souza et.al [19], the overall credibility of the Portuguese data is very high and the data can be considered credible and usable, despite some particular cases of diagnosis that have less cohesive date.

This paper is organized as follows: In Section 2 the original DRG data and the transformed data used in this study are explained as well as the description of the methodology used in the exploratory analysis and in the fitting of the distributions. In Section 3 the exploratory analysis is performed, in which the LoS and $\mathrm{TuD}$, number of entries, fatalities and other parameters, for either ICU and non-ICU patients, is characterized and compared between genders, age groups and regions, as well as their evolution over time. In Section 4 the results from this study are discussed. An appendix section $\mathrm{A}$ is also provided, with an extended explanation of the data and all transformations carried out and also more extensive graphs and tables and other relevant information. 


\section{METHODS}

\subsection{Data}

The data used in this study was obtained from the BI-MH platform of the SPMS/ACSS (Ministry of Health Shared Services / Central Administration of the Health System, IP) services of Portugal and is composed by the DRG data, with hospital discharges, having a COVID-19 diagnosis.

The DRG data was restructured in order to obtain the age of the patients and their respective age group, the regional health administration (ARS) to which the hospital belongs, $\mathrm{LoS}$ and $\mathrm{TuD}$, as explained in the appendix A.1. This new data, containing 54685 entries, is described in appendix A.2, where the used variables are identified and explained. Because the DRG data is recorded only when a patient is discharged, a right truncation problem arises. In order to overcome this, we disregard admissions from the last two months, as explained in the appendix A.3. As such the considered data ranges are from 1 of March 2020 to 31 of March 2021. Additionally, from this restructured data, the admissions were aggregated by day. The type of hospitalisation is distinguished between:

- Non-ICU patients: patients who have not received treatment in intensive care units during their stay in the hospital;

- ICU patients: patients who received treatment intensive care units during their hospitalisation.

The regions used follow the areas of the regional health administrations (ARSs) established by the Portuguese national health service (SNS). The population numbers for each region were extracted from the Portuguese Central Administration of the Health Service (ACSS) website (data from June 2016 link1). The five considered ARSs that cover Continental Portugal are: ARS Norte, ARS Centro, ARS Lisboa e Vale do Tejo (LVT), ARS Alentejo and ARS Algarve. The Portuguese autonomous regions (Açores and Madeira) are not included in the study due to lack of data.

The population estimates (total and by gender) correspond to the resident population in Continental Portugal and were extracted from the census 2021 data, elaborated by Statistics Portugal (INE), the Portuguese official statistical institution, and is avaliable at INE website at link2. The population numbers by age group correspond to the provisional resident population data obtained from the census data, available at the link3.

A table containing the number of hospital entries, the population number for Portugal and percentages calculated from these values was used in several 
analysis, being presented in the appendix A.1 in table 3 . The daily data is presented in appendix A.2 tables 4567 and 8.

Summary statistics complementary to the various Violin/box plots and histograms are available in appendix A.4. Extra graphs of interest may be found in appendix A.5. All data processing and analysis was done using $R$ [14].

\subsection{Distribution fitting}

The probability distributions of the LoS and TuD, for non-ICU and ICU patients, were also studied using the $\mathrm{R}$ fitdistrplus package [5]. The objective of this analysis was to find the probability distribution that best describes the observed data. To enable the use of the Weibull distributions the episodes with 0 days of stay were removed.

To choose the candidate distributions to be fitted to the data we used different tools of fitdistrplus. In addition to empirical plots, like density histograms and the plots of the empirical cumulative distribution function, the descriptive statistics provided helps in this choice, specially the Skewness-kurtosis plot (figure 11), also known as Cullen and Frey graph, with a nonparametric bootstrap procedure to take into account the uncertainty in the estimation of kurtosis and skewness from data.

The next step was to fit the chosen distributions to the data. The default method of estimation uses the maximum likelihood function, which was used in all chosen distributions to be fitted. With the objective to give more weight to the left tail of the distribution, as the data has many large outliers, the maximum goodness-of-fit estimation using the left-tail Anderson-Darling (ADL) distance was used in the two best fitted distributions, the gamma and log-normal distributions.

To evaluate the fit of the candidate distribution, various goodness-of-fit statistics (Kolmogorov-Smirnov, Cramer-von Mises and Anderson-Darling statistic) and goodness-of-fit criteria (Aikake's and Bayesian information criterion) are provided in the appendix A.4. 


\section{RESULTS}

\subsection{Exploratory data analysis}

One of the most important parameters related to hospitalisation is the length of stay (LoS), as the rate of exits from hospital and the number of occupied beds are dependent on it. In figure 1 a violin/box plot, together with histograms, related to LoS for either type of hospitalisation are presented, obtaining a mean of 12.5 days and a median of 8 days (IQR:4-15) for non-ICU patients and a mean of 24.3 days and median of 18 days (IQR:11-30) for ICU patients (extended summary statistics avaliable at appendix A.4 table 10. There is a clear difference in LoS between non-ICU and ICU patients.

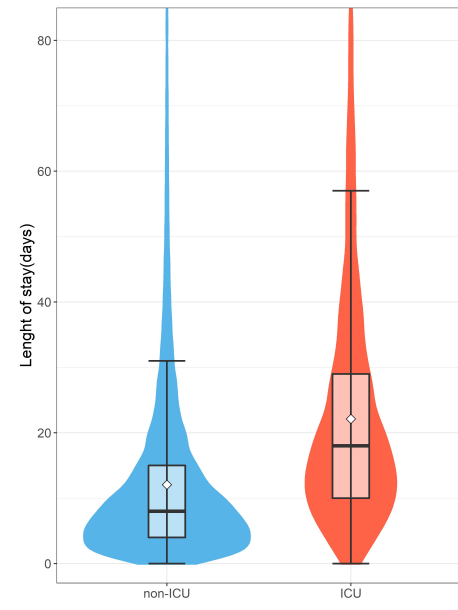

(a)
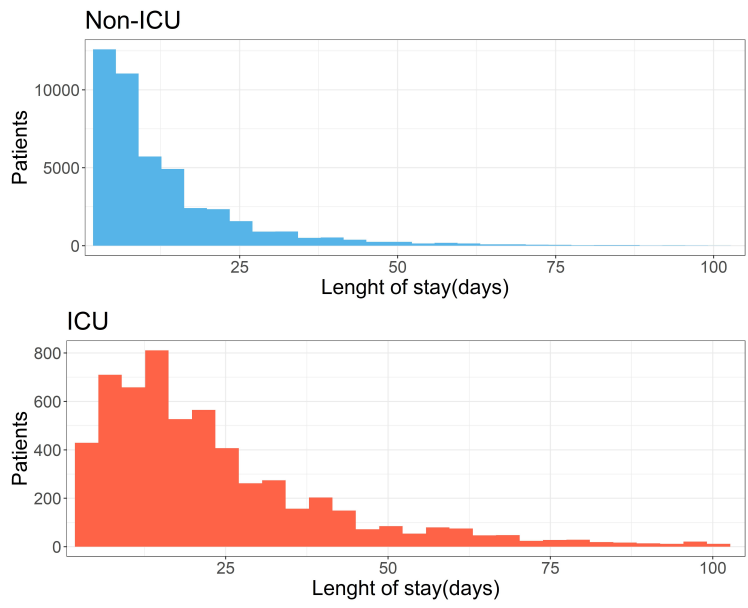

(b)

Figure 1: Distribution of the LoS in hospital care. (a) Violin/box plot of the length of stay by type of hospitalisation, in which the white diamond represents the mean. (b) Distribution of the LoS for non-ICU and ICU patients (white diamonds represent the mean).

There are two possible hospitalisation outcomes, either the patient is discharged from hospital or he dies. Considering these outcomes a violin/box plot comparing time until death (TuD) and time until Discharge (TuDisc) is presented in figure 2, with summary statistics available in appendix A.4 in table 11. The TuD mean and median are 11.01 and 7 days for non-ICU, and 20.04 and 16 for ICU, respectively, and for TuDisc the mean and median are 12.98 and 9 for non-ICU and 26.39 and 19 days for ICU patient.

Three parameters that describe the hospitalisation dynamics were esti- 


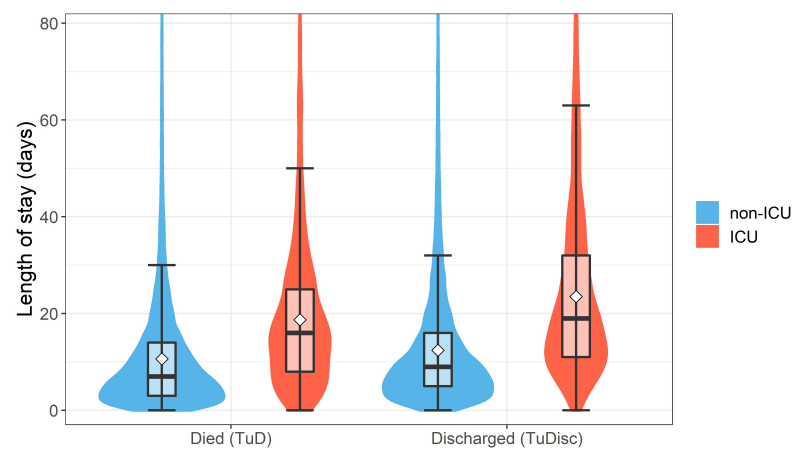

Figure 2: Violin/Box plot of the length of stay (LoS) for each outcome (Death or Discharge) and type of hospitalisation (non-ICU and ICU) (white diamonds represent the mean).

mated as follows:

$$
\begin{aligned}
\text { Percentage of ICU patients } & =\frac{\text { ICU entries }}{\text { Total entries }} \times 100 \%=10.92 \% \\
\text { Non-ICU COVID-19 fatality rate } & =\frac{\text { non-ICU fatalities }}{\text { non-ICU entries }} \times 100 \%=22.60 \% \\
\text { ICU COVID-19 fatality rate } & =\frac{\text { ICU fatalities }}{\text { ICU entries }} \times 100 \%=32.84 \%
\end{aligned}
$$

\subsubsection{Characterization over time}

One of the characteristics of the COVID-19 pandemic is the peak in cases that occurs in different periods of time. The number of hospitalizations follows the number of cases and therefore is also prone to rapid peaks in hospitalisation. This is specially problematic for health services since this could lead to a lack of hospital capacity and affect the care to be provided.

We found an association between number of hospitalizations and the fatality rate, the higher the number of hospital entries the higher the in-hospital fatality rate and the decrease in the LoS of the patients that died, as seen in figure 3 . There is visible the increase in fatality rate with the increase in cases related to the second surge in hospitalisation from September to February 2020.

Violin/box plots for either LoS and TuD over time are available in appendix A.5, in figure 14 (a) and (b), linegraphs with hospital occupancy, discharges and 
fatalities over time are also available in figure 15. Summary statistics for LoS 2 and $\mathrm{TuD}$ are displayed in appendix A.4 table 12 and 13 .

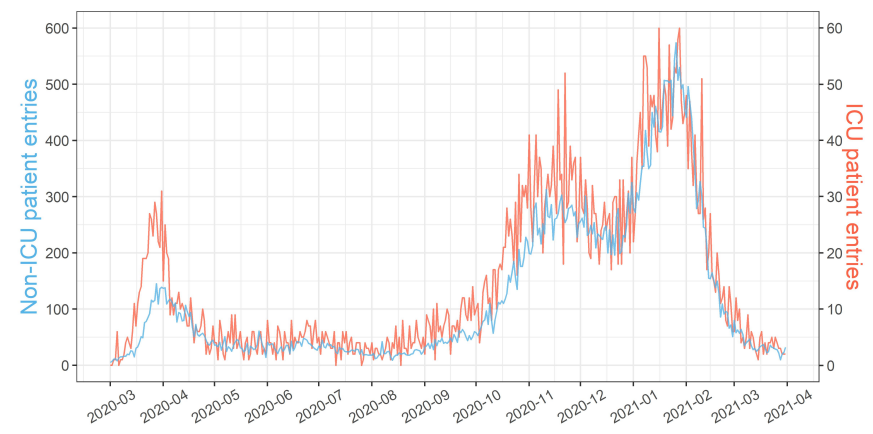

(a)

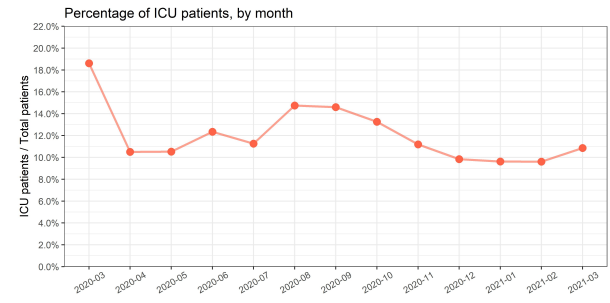

(b)

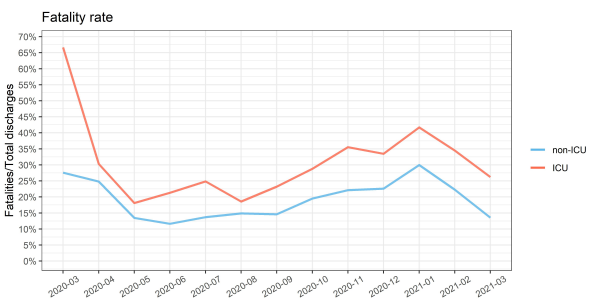

(c)

Figure 3: (a)Entries, (b)percentage of ICU patients and (c)fatality rate, over time and by type of hospitalisation

\subsubsection{Characterization by age}

It is well known that COVID-19 affects more the elderly, increasing the risk of hospitalisation, severe illness and death. This was visible in the data as fatality rate increases with age, as shown in figure 5(b), as well as a higher percentage of hospitalized population (appendix A.5, figure 17(a) and (b)). The probability of being admitted to ICU was also higher for patients with 60 to 69 years of age, decreasing afterwards. This makes us conclude that the probability of entering ICU for older patients is lower.

The group from 10 to 15 years old is the one with the lower number of entries, but where the percentage of ICU patients and the fatality rate is higher than the 0 to 10 groups and the 15 to 20 group. This anomaly is not exclusive to Portugal and was reported by the Center of Disease Control and Prevention (CDC) [10]. 
medRxiv preprint doi: https://doi.org/10.1101/2022.03.03.22271349; this version posted March 6, 2022. The copyright holder for this preprint (which was not certified by peer review) is the author/funder, who has granted medRxiv a license to display the preprint in perpetuity.

It is made available under a CC-BY-NC 4.0 International license .

COVID-19 Hospitalisation in Portugal, the first year: Results from hospital discharge data

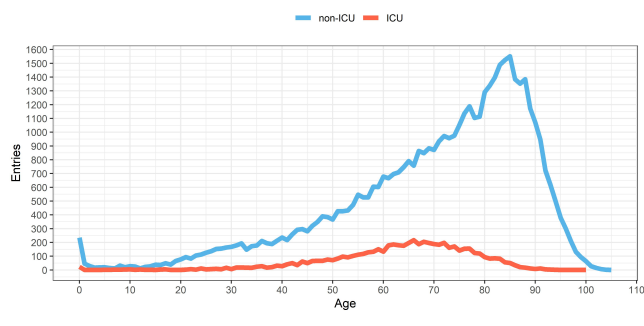

(a)

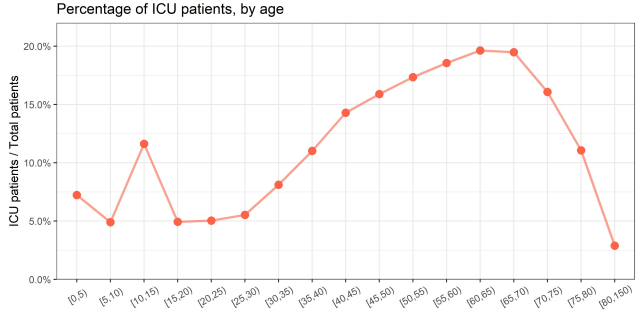

(b)

Figure 4: Hospital entries by age: (a)entries and (b)percentage of patients requiring ICU treatment.

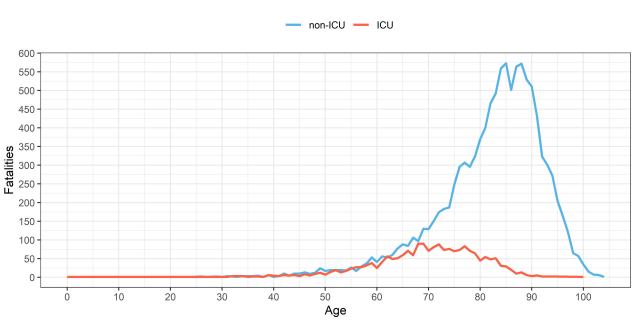

(a)

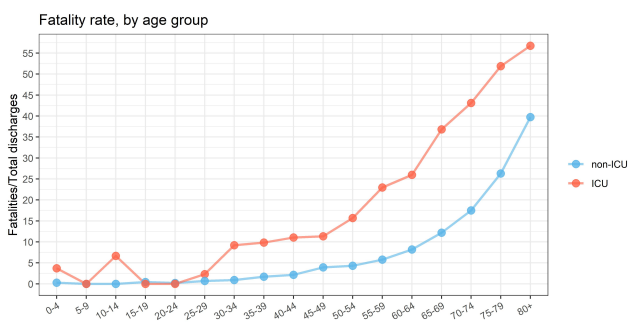

(b)

Figure 5: Mortality by age: (a)number of fatalities and (b)in-hospital fatality rate.

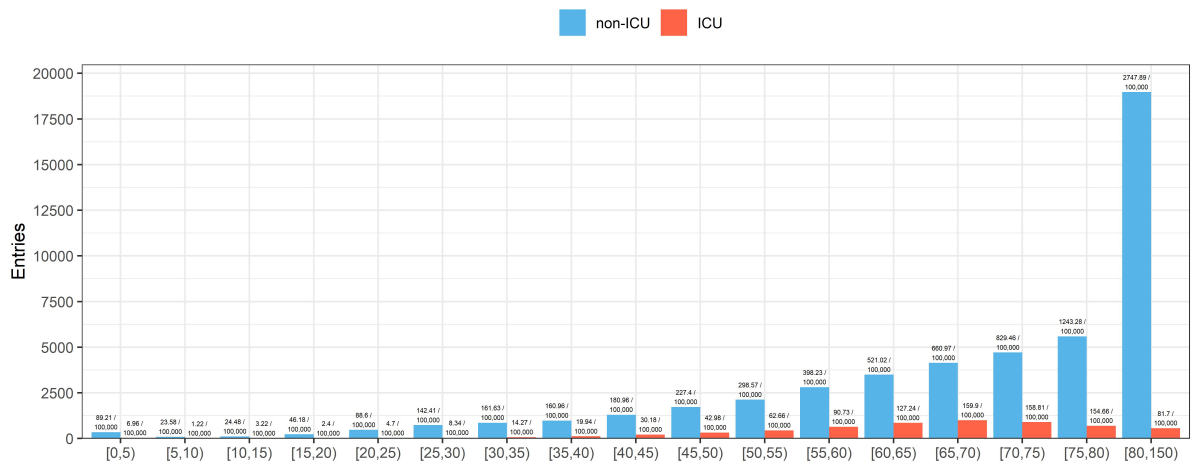

(a)

Figure 6: Hospital entries by age group and type of hospitalization.

\subsubsection{Characterization by gender}

Looking at gender differences in COVID-19 hospitalisation, there is a clear difference in the total number hospitalisation, where males were more hospitalized than females, with percentage of the population hospitalized in non-ICU of $0.51 \%$ 
medRxiv preprint doi: https://doi.org/10.1101/2022.03.03.22271349; this version posted March 6, 2022. The copyright holder for this preprint (which was not certified by peer review) is the author/funder, who has granted medRxiv a license to display the preprint in perpetuity.

It is made available under a CC-BY-NC 4.0 International license .

for males and $0.45 \%$ for females, and for ICU $0.08 \%$ for males and $0.03 \%$ for females. Male patients also have a higher fatality rate than females. For non-ICU, males patients have a $23.23 \%$ mortality rate and female patients have $21.95 \%$, for ICU patients males have $33.81 \%$ and females $30.70 \%$.

Violin/box plots for the LoS considering gender and age groups are presented in appendix A.5 figure 20, where it is observable that the LoS are similar between group's gender, being the only exceptions the groups of the 25-30 and 30-35 for non-ICU patients were a large difference between genders arises. In the case of $\mathrm{TuD}$ there is also no observable difference, as seen in appendix A.5 figure 19 .

In the Appendix A.5 figure 22 multiple graphs considering the differences between gender and type of hospitalization are presented. It is visible a lower number of entries and fatalities in females in general, with the females only being the group with more entries and fatalities in the 80 and over group for non-ICU patient type. Males have specially high numbers of entries and fatalities in ICU when compared to females.

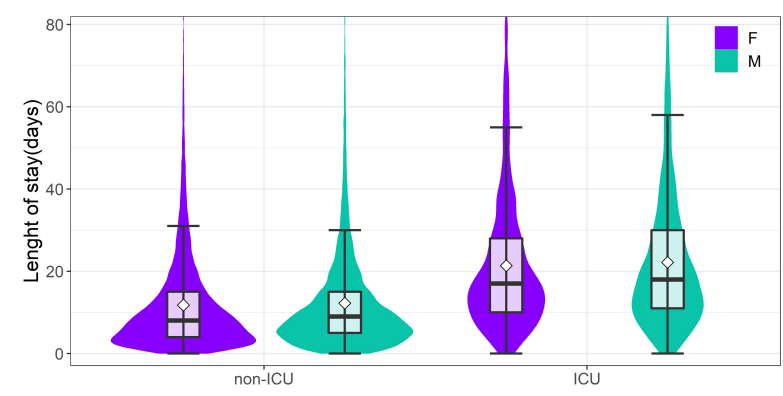

(a)

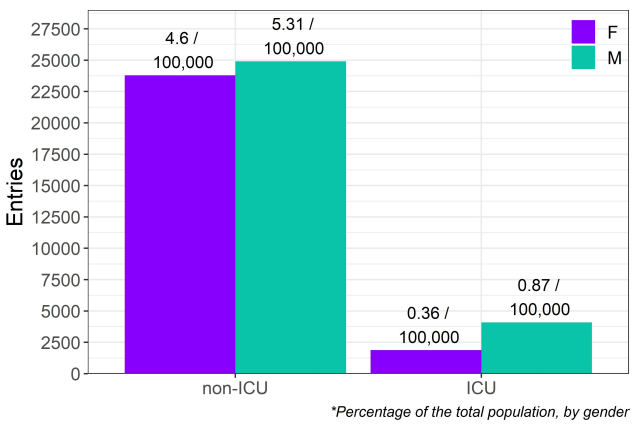

(b)

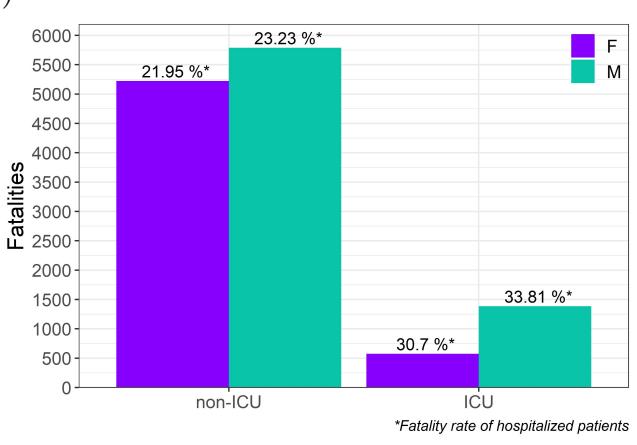

(c)

Figure 7: Hospital entries by gender ( $\mathrm{F}$ for female and $\mathrm{M}$ for male, white diamonds represent the mean). (a)Violin/box plot of the LoS by gender and type of hospitalisation, (b)total number of entries by gender and type of hospitalisation and (c)total number of fatalities by gender and type of hospitalisation, with fatality rates. 
medRxiv preprint doi: https://doi.org/10.1101/2022.03.03.22271349; this version posted March 6, 2022. The copyright holder for this preprint (which was not certified by peer review) is the author/funder, who has granted medRxiv a license to display the preprint in perpetuity.

It is made available under a CC-BY-NC 4.0 International license .

COVID-19 Hospitalisation in Portugal, the first year: Results from hospital discharge data 11

\subsubsection{Characterization by region}

The SARS-CoV2 geographical spread through Portugal was not uniform, with regions having increases and decreases in incidence in different periods, although the increase in cases in one region seems to spread to all other regions, as can be seen in appendix A.5 figure 25

This leads to the differences in the percentage of the population admitted to hospital by region, observed in figure 8 , with the $L V T$ region being the one with the biggest percentage of hospitalization rate, followed by the Norte and Centro regions, other very populous regions. This could be explained by the higher population density of these regions that makes social distancing less efficient and by the transfer of patients from smaller hospitals located in less populated regions to larger ones, in big cities like Lisboa (LVT region), Porto (Norte region) and Coimbra (Centro).

No major difference was found between LoS and TuD by region, as seen in appendix A.5 figure 25. Looking at the percentage of patients requiring ICU treatment the Centro region has the lower and the Algarve region the higher percentage.
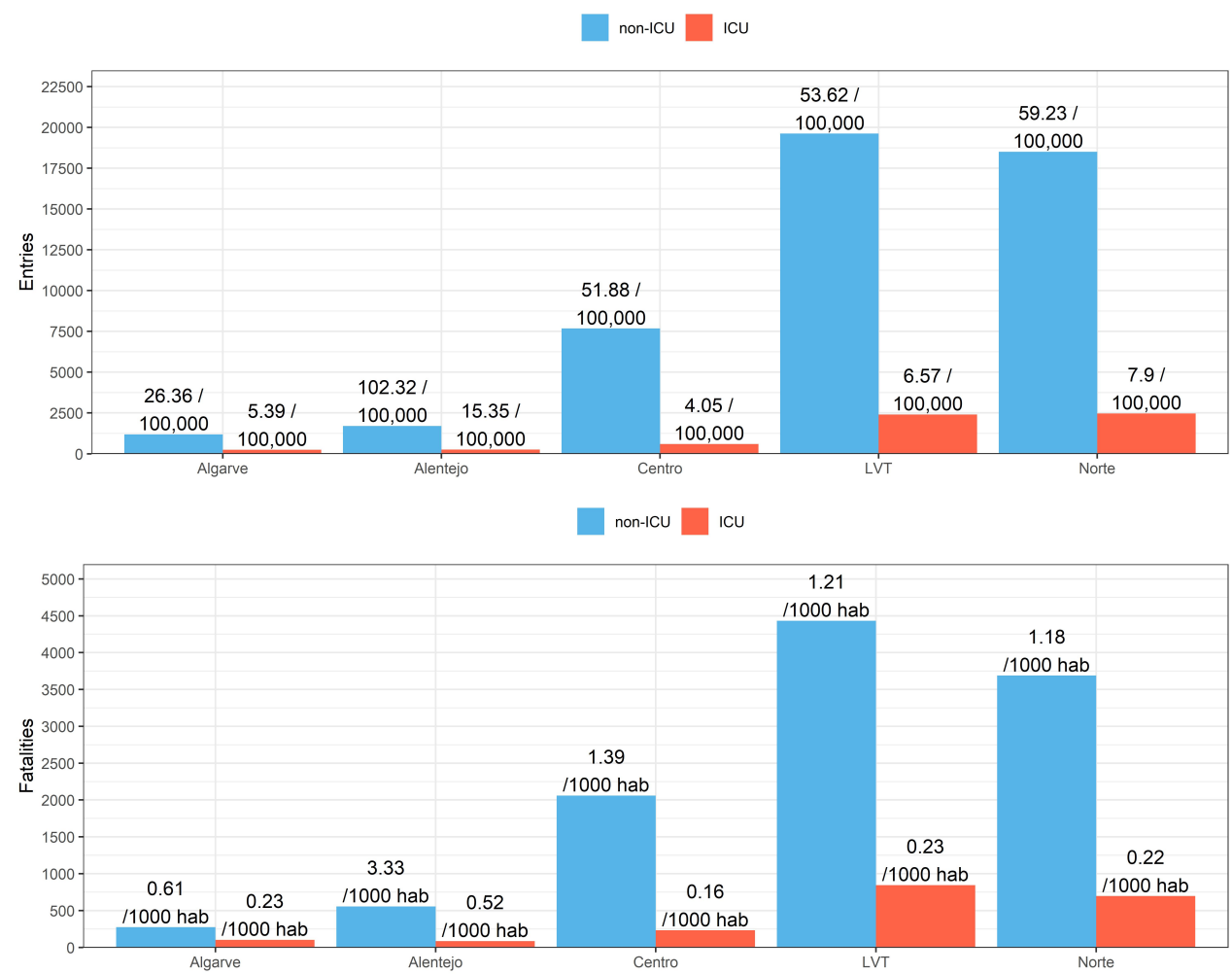

Figure 8: Number of (a)entries and (b)fatalities, by region and type of hospitalisation. 


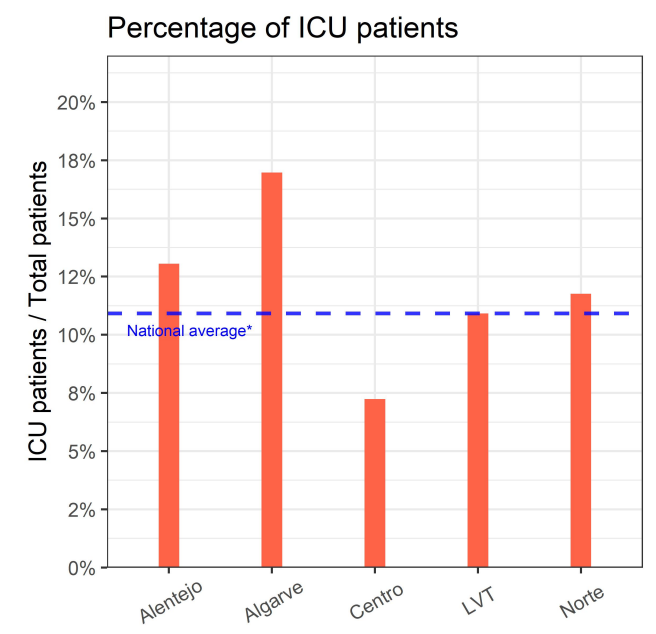

Figure 9

Figure 10: Percentage of ICU patients, by region.

\subsection{Distribution fitting}

An analysis of the distribution of the LoS was conducted as explained in section 2. Using the Cullen and Frey graphs (figure 11) we chose the distributions that best fitted each sample of the LoS type of hospitalisation, non-ICU and ICU. From the interpretations of those graphs the gamma, lognormal and Weibull distributions were the ones chosen to be fitted to the data. A table with the summary statistics used to plot these graphs is available in the appendix A.6 table 14 .

After fitting the previously chosen distributions, for each type of hospitalisation (non-ICU and ICU), using the maximum likelihood estimation method, we compared them by using goodness-of-fit plots and the goodness of fit statistics and criteria supplied in the fitdistrplus package. We also estimated the gamma and log-normal distribution by fitting using the Left-tail AD variant of the AndersonDarling distance. Tables with all the results are present in appendix A.6 (see 16 and 17).

The graphs in figure 12 represent all fitted theoretical distributions to the data for non-ICU and ICU patients. All estimated parameters are available in the appendix A.6 in table 15. For non-ICU patients the lognormal distribution (mean-log 2.1195 and sd-log 0.9496) was the distribution with the lower goodnessof-fit(GoF) statistics, except for the Anderson-Darling statistic that was lower in the lognormal ADL distribution (mean-log 2.1465 and sd-log 0.9886). The lognormal distribution (mean-log 2.8583 and sd-log 0.8655) also had lower GoF statistics for ICU patients, excepting for Kolmogorov-Smirnov and AndersonDarling statistics that where lower for lognormal ADL distribution (mean-log 
medRxiv preprint doi: https://doi.org/10.1101/2022.03.03.22271349; this version posted March 6, 2022. The copyright holder for this preprint (which was not certified by peer review) is the author/funder, who has granted medRxiv a license to display the preprint in perpetuity.

It is made available under a CC-BY-NC 4.0 International license .

COVID-19 Hospitalisation in Portugal, the first year: Results from hospital discharge data 13

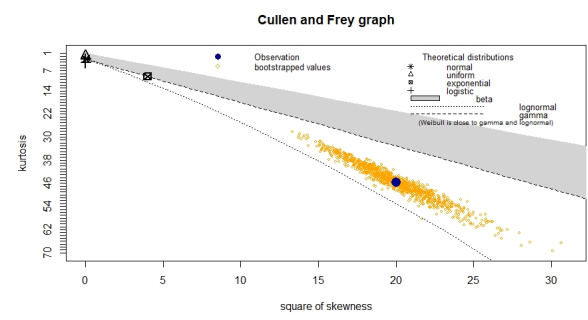

(a)

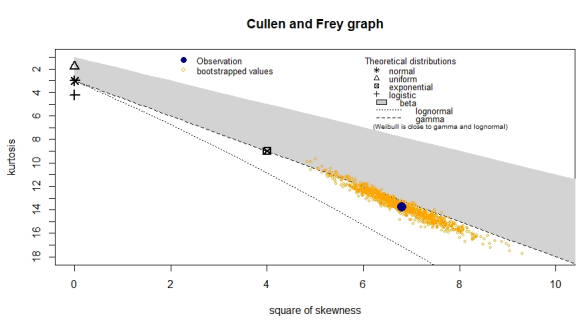

(b)

Figure 11: Cullen and Frey graphs for (a)Non-ICU and (b)ICU patients.

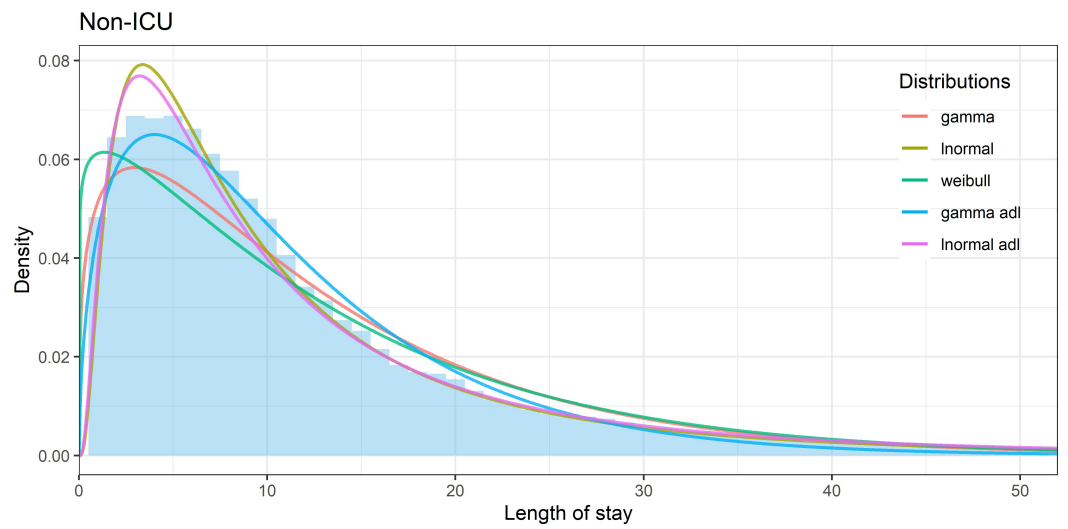

(a)

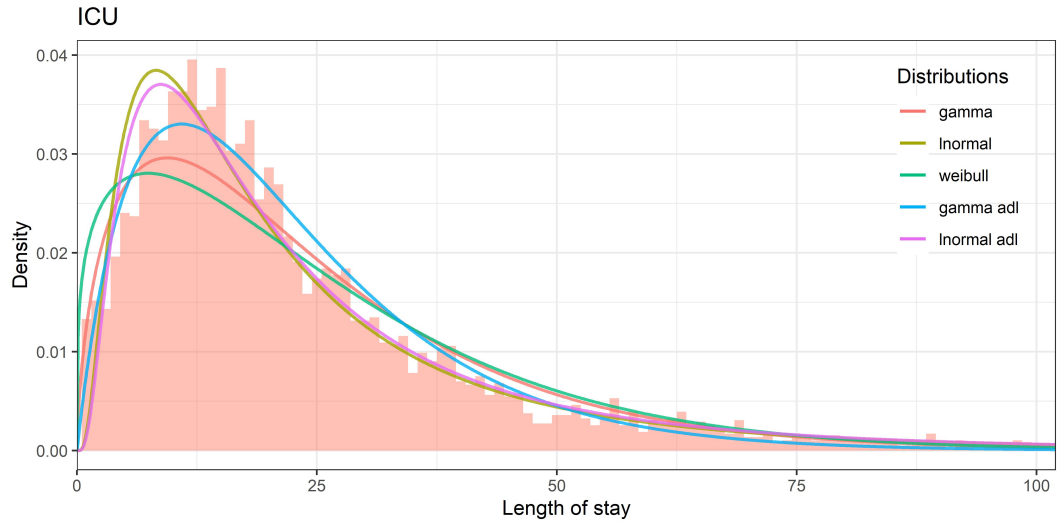

(b)

Figure 12: Fitted distributions to the LoS for (a)non-ICU (Hosp) and (b)ICU patients.

The same analysis was carried out to the TuD, with the Cullen and Frey 3 graphs and statistics being presented in figure 26 and table 18 , and a table with 4 the parameters for all fitted distribution in tables 19, in appendix A.6. Compar- 


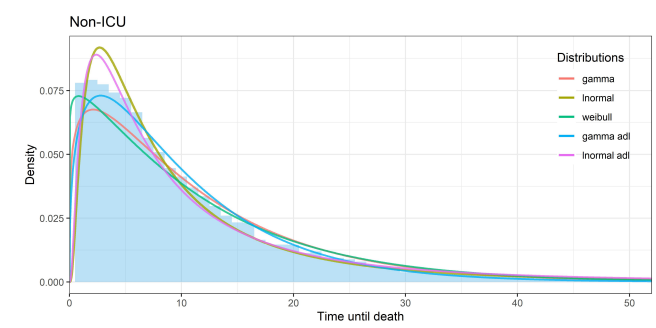

(a) distribution (rate 1.7360 and rate 0.0888 ).

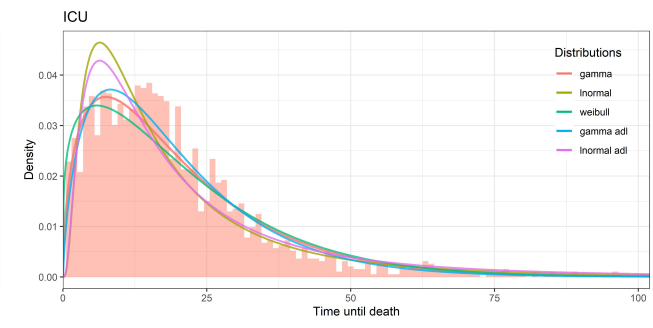

(b)

Figure 13: Fitted distributions to the time until death for (a)non-ICU and (b)ICU patients.

\section{DISCUSSION}

ing goodness of fit statistics, for the non-ICU patients the lognormal distribu(mean-log 1.9684 and sd-log 0.9873) had lower values for Anderson-Darling alkaike's and Bayesian Information Criterion, with the gamma disSmirnov and Cramer-von Mises statistics. For ICU patients the gamma distribution (shape 1.5799 and rate 0.0779 ) had lower values for all but KolmogorovSmirnov and Cramer-von Mises statistic that were lower for the gamma ADL

From the analysis of Portuguese DRG data the mean length of stay (LoS) was estimated as 12.5 (IQR: 4-15) for patients without ICU hospitalization and 24.3 days (IQR: 11-30) for patients who received ICU treatments, with it being higher in the case of recovery when comparing with in the case of hospital fatality. No meaningful differences were found in LoS between genders and regions, but differences where found between age groups and over time, with older groups having a higher LoS. The mean time until death $(\mathrm{TuD})$ and time until discharged (TuDisc) was also estimated as 11.01 and 12.94 for non-ICU patients and 20.06 and 26.39 days for ICU patients.

The percentage of patients that required entry in ICU was estimated as $10.92 \%$ and the fatality rate as $22.60 \%$ for non-ICU patients and $32.84 \%$ for ICU, with the percentage of ICU patients changing depending in patient age and the region of hospitalization. The fatality rate was different between age group, gender and region, for either non-ICU and ICU patients.

Various distributions were fitted to the density plots of the LoS and $\mathrm{TuD}$, for either non-ICU and ICU patients, with the estimated distributions parameters being presented in the Appendix A.6 in table 15 for LoS and table 15 for TuD. Log-normal and log-normal ADL have better goodness-of-fit statistics for LoS of non-ICU and ICU and for TuD of non-ICU, gamma and gamma ADL have better fits for TuD of ICU patients. 
In [9, the authors consider various distributions that were fitted to the hospitalized patients clinical database of Belgium, with the length of stay for patients that recover being estimated as between 5 days (in the young population) to 15.7 (in the elderly) and the median length of stay for patients that die between 5.7 days (in the elderly) and 12.2 days (in the working age population). Our study distinguishes between non-ICU and ICU patients but the LoS, TuD and TuDisc follow the trends presented by [9], increasing with the age of the patient. This study also refers that the LoS is higher for males, what was not observed in our study. A lognormal distribution was used to describe the LoS in hospital $(\log$-mean $=2.480$ and $\log$-sd $=0.913 ; \mathrm{IBM}=76,865)$ and in ICU $(\log$-mean $=$ 2.183 and $\log$-sd $=1.052 ; \mathrm{IBM}=7312)$, the $\operatorname{LoS}$ for recovery and death was also analysed.

From a retrospective cohort study of Portuguese surveillance data, Peixoto[16] identifies a consistent increase in risk of ICU admission with age until the 70-79 age group, with decreased risk for subsequent age groups. In our study the risk increases until age 60-75 age group, decreasing afterward, as can be seen in Figure 4(b). In regards to mortality, Peixoto[16] claims a constant increase of risk of death with age, which is also visible in our data, specially in in Figure 5(b).

In her paper Vekaria [13] estimates the various LoS, for the UK, using three different statistical methods. With LoS for non-ICU patients being between 8.4 and 9.3 days and for ICU being between 16.2 and 35.2 days. The study also presents the time from hospital entry to ICU as being between 2 to 4 days and the time from ICU exit to full hospital release being between 1.8 and 8.4 days.

In Rees [15] paper a systematic review of early evidence on LoS of patients was conducted. This paper estimates the parameters from all published papers up to 12 April 2020. According to this the mean length of stay, for countries outside of China, is 11.0 days in hospital (non it ICU) and 12.2 in ICU. The LoS in hospitalisation, and the decrease in length of stay with time in the beginning of the pandemic reported in this study is also visible in our data.

One of the limitations of the data used is the lack of distinction between length of stay in ICU care and the overall time in hospital care for a patient that received ICU treatment, as the LoS refers to the total time in hospital. Unfortunately, there are not very many studies presenting LoS, as Rees [15] also report, LoS is normally not the primary measure of interest in studies which report it, and most of them consider LoS in ICU as time in ICU hospitalisation, what makes comparing them with our data difficult. Another limitation comes from the fact that the database BI-MH does not include hospitalizations in private hospitals or other non-public healthcare providers. Other factor to take in consideration, as it overestimates entries in hospital care, is that hospital transfers count as new entries and therefore a patient can have multiple consecutive entries.

Our objective with this study was to elucidate the COVID-19 hospitalization dynamics in Portugal. We took advantage of the DRG data to explore time in hospital care and other important parameters providing the necessary 


\section{ACKNOWLEDGMENTS}

\section{REFERENCES}

[1] Angelico R.; Trapani S.; Manzia, T. M.; Lombardini, L.; Tisone G. And CARDILlo, M. (2020) The COVID-19 outbreak in Italy: Initial implications for organ transplantation programs, $R$ Foundation for Statistical Computing doi: 10.1111/ajt.15904.

[2] Caetano C.; Morgado M. L.; Patrício P.; Pereira J. F. and Nunes B. (2021) Mathematical Modelling of the Impact of Non-Pharmacological Strategies to Control the COVID-19 Epidemic in Portugal, Mathematics Vol. 9, No. 10, p. 1084, doi: $10.3390 /$ math9101084.

[3] Centro de Terminologias Clínicas (2020/2021) Catálogo Português ICD-10-CM/PCS V5.0, 16-12-2020 link: https://www.ctc.min-saude.pt/wpcontent/uploads/2020/03/DocEsp_ICD10CMPCSv5.0.pdf

[4] Cucinotta D. And Vanelli M. (2020) WHO Declares COVID-19 a Pandemic Acta Bio Medica Atenei Parmensis Vol. 91, 157-160, doi: 10.23750/abm.v91i1.9397

[5] Delignette-Muller M. L. And Dutang C. (2015) fitdistrplus: An R Package for Fitting Distributions, Journal of Statistical Software, Articles Vol. 64, No. 4, 1-34, doi: $10.18637 /$ jss.v064.i04.

[6] Diário da República Eletrónico (2020) Legislação Compilada-COVID-19, url: https ://dre.pt/legis lacao -covid -19-upo. 
COVID-19 Hospitalisation in Portugal, the first year: Results from hospital discharge data 17

\begin{abstract}
[7] Directorate-General of Health (Portuguese: Direção-Geral da SAÚDE; DGS) (2021) Situation Report No $394-31 / 03 / 2021$

[8] Eurostat - European Commission (2020) Statistical regions in the European Union and partner countries: NUTS and statistical regions 2021: 2020 edition, Publications Office doi: 10.2785/72829

[9] Faes C.; Abrams S.; Van Beckhoven D.; Meyfroidt G.; Vlieghe E.; Hens N. and Belgian Collaborative Group on COVID-19 Hospital Surveillance (2020) Time between Symptom Onset, Hospitalisation and Recovery or Death: Statistical Analysis of Belgian COVID-19 Patients International Journal of Environmental Research and Public Health Vol. 17 No. 20, 7560, doi: 10.3390/ijerph17207560

[10] Havers F. et al. (2009) Hospitalization of Adolescents Aged 12-17 Years with Laboratory-Confirmed COVID-19 - COVID-NET MMWR. Morbidity and Mortality Weekly Report, 2021 No. 23, 851-857, doi: 10.15585/mmwr.mm7023e1

[11] Harjule P.; Tiwari V. And Kumar A. (2021) Mathematical models to predict COVID-19 outbreak: An interim review, Journal of Interdisciplinary Mathematics Vol. 24, No. 2, 259-284, doi: 10.1080/09720502.2020.1848316.
\end{abstract}

[12] Kretzschmar M.; Wallinga J. (2009) Mathematical Models in Infectious Disease Epidemiology. In: Krämer A., Kretzschmar M., Krickeberg K. (eds) Modern Infectious Disease Epidemiology Statistics for Biology and Health, 209-221, doi: 10.1007/978-0-387-93835-6_12

[13] Vekaria, B., Overton, C., Wiśniowski, A. et al. (2021) COVID-19 length of hospital stay: a systematic review and data synthesis BMC Infect Dis Vol. 21 No. 700, doi: 10.1186/s12879-021-06371-6

[14] R Core Team (2020) R: A Language and Environment for Statistical Computing, American Journal of Transplantation Vol. 20, No. 7, 1780-1784, url: https://www.R-project.org/

[15] Rees, E.M., Nightingale, E.S., Jafari, Y. et al. (2020) Hospital Length of Stay For COVID-19 Patients: Data-Driven Methods for Forward Planning BMC Med Vol. 18 No. 270, doi: 10.1186/s12916-020-01726-3

[16] Ricoca Peixoto V.; Vieira A.; Aguiar P.; Sousa P.; Carvalho C.; Thomas D.; Abrantes A. and Nunes C. (2020) COVID-19 :Determinants of Hospitalization, ICU and Death among 20,293 reported cases in Portugal medRxiv 2020.05.29.20115824 doi: 10.1101/2020.05.29.20115824

[17] Sarmadi M.; Kakhki S.; Foroughi M.; Abadi T.S.H.; Nayyeri S.; Moghadam V.K. and Ramezani M. (2020) Hospitalization period of COVID-19 for future plans in hospital, British Journal of Surgery Vol. 107, No. 10 e427-e428, doi: $10.1002 /$ bjs. 11871.

[18] Silva C.J.; Cruz C.,Torres D.F.M.; Muñuzuri A.P.; Carballosa A.; Area I., Nieto J.J.; Fonseca-Pinto R.; Passadouro R.; dos Santos E.S.; Abreu W. ANd Mira J. (2021) Optimal control of the COVID-19 pandemic: controlled sanitary deconfinement in Portugal Scientific Reports Vol.11, No. 1, doi: $10.1038 / \mathrm{s} 41598-021-83075-6$

[19] Souza J.; Pimenta D.; Caballero I. and Freitas A. (2020) Measuring data credibility and medical coding: a case study using a nationwide Portuguese inpatient database Software Quality Journal Vol. 28 No. 3, 1043-1061, doi: 10.1007/s11219-020-09504-3 
medRxiv preprint doi: https://doi.org/10.1101/2022.03.03.22271349; this version posted March 6, 2022. The copyright holder for this preprint (which was not certified by peer review) is the author/funder, who has granted medRxiv a license to display the preprint in perpetuity.

$$
\text { It is made available under a CC-BY-NC } 4.0 \text { International license. }
$$

[20] Mangia C., Russo A., Civitelli S. and Gianicolo E. A. L. (2020). differenze sesso/genere nella letalità COVid-19: cosa dicono e non dicono i dati Epidemiologia \& Prevenzione, No. 44(5-6 Suppl 2) 400-406 doi:10.19191/EP20.5-6.S2.145 
medRxiv preprint doi: https://doi.org/10.1101/2022.03.03.22271349; this version posted March 6, 2022. The copyright holder for this preprint (which was not certified by peer review) is the author/funder, who has granted medRxiv a license to display the preprint in perpetuity.

It is made available under a CC-BY-NC 4.0 International license .

COVID-19 Hospitalisation in Portugal, the first year: Results from hospital discharge data 19

\section{A. APPENDIX}

\section{A.1. Data processing}

\begin{tabular}{|c|c|}
\hline Variable & Description \\
\hline $\begin{array}{l}\text { Health institu- } \\
\text { tion }\end{array}$ & Institution where the entries took place \\
\hline Gender & Gender of the patient \\
\hline Date of birth & Birth date of the patient \\
\hline $\begin{array}{l}\text { Hospital pro- } \\
\text { cess }\end{array}$ & Anonymised data related to the hospital process number \\
\hline $\begin{array}{l}\text { Hospital } \\
\text { episode }\end{array}$ & Anonymised data related to the hospital episode number \\
\hline $\begin{array}{l}\text { Destination af- } \\
\text { ter discharge }\end{array}$ & $\begin{array}{l}\text { Destination of the patient after medical discharge, in- } \\
\text { cluding death. }\end{array}$ \\
\hline Discharge date & Date the patient was discharged from the hospital \\
\hline Entry date & Date the patient entered hospital care \\
\hline $\mathrm{ICU}$ & Whether or not the patient was in ICU care \\
\hline Type of episode & $\begin{array}{l}\text { Time of stay in hospital care groups (short term, normal, } \\
\text { long term and prolonged evolution) }\end{array}$ \\
\hline Diagnostic code & $\begin{array}{l}\text { Diagnosis-related groups (DRG) code, in this case all en- } \\
\text { tries have the U071 code, that identifies COVID-19 di- } \\
\text { agnosis. }\end{array}$ \\
\hline Diagnostic & $\begin{array}{l}\text { Diagnostic represented by the Diagnostic code, in this } \\
\text { case all entries have the COVID-19 diagnostic }\end{array}$ \\
\hline $\begin{array}{l}\text { Diagnostic } \\
\text { order }\end{array}$ & Order of diagnostic of the patient in that day \\
\hline
\end{tabular}

Table 1: Variable identification of the provided DRG data

The original Portuguese DRG data used in this was extracted from the BI$\mathrm{MH}$ platform of the SPMS/ACSS services of Portugal and provided to us with the following structure:

The original DRG data, explained in the previous table 1, was transformed before use as to have the variable identified in table 2. The next list presents all modifications that were performed:

7 - From the "Health institution" column, all institutions were distributed 


\begin{tabular}{l|l} 
Variable & Description \\
\hline Region & $\begin{array}{l}\text { ARS of the health institution (Norte, Centro, LVT, Alen- } \\
\text { tejo e Algarve) }\end{array}$ \\
Age & $\begin{array}{l}\text { Age of the patient, at the time of entry } \\
\text { Gender of the patient }\end{array}$ \\
Gender & $\begin{array}{l}\text { Patient entry date to the health institution } \\
\text { Entry date }\end{array}$ \\
$\begin{array}{l}\text { Discharge date } \\
\text { Pestination af- } \\
\text { ter discharge }\end{array}$ & $\begin{array}{l}\text { Destination after medical discharge, includes as a out- } \\
\text { come death. }\end{array}$ \\
Length of stay & $\begin{array}{l}\text { Length of stay in heath care, corresponds to number of } \\
\text { days between the discharge date and the entry date, in } \\
\text { days } \\
\text { Age group corresponding to the age of the patient }\end{array}$ \\
\hline Group &
\end{tabular}

by the ARS (Regional Health Administration) to which they belong and grouped in the "Region" column.

- From the "Date of birth" column the age of the patient at the time of entry was determined and introduced in the "Age" column;

- The "ICU" column had the name changed to "Local" and the designations changed, with "non-ICU" representing non-ICU patients and "ICU" for patients that received any ICU care;

- A column with the length of stay was added, being calculated by subtracting the entry date to the discharge date;

- Using the "Age" column, the patients where divided by age groups in a column named "Group", with ages from 0 to 80 housed in 5 year gaps groups and the 61 and up being grouped in a single group;

- Unused columns were removed in order to facilitate the analysis.

\section{A.2. Variables identification}

In table 2 the variables used in the study are explained. They where obtained from the restructuring of the original DRG data, as is explained in section A.1.

Table 2: Variable identification of the used data, restructured from the DRG data

18 either non-ICU and ICU patients, having obtained the table 3 , with the entries 
COVID-19 Hospitalisation in Portugal, the first year: Results from hospital discharge data 21

The regions represent the ARS to which the hospital where the entry occurred belongs to. With the population numbers used being relative to the population that is covered by each region (link1). Data from the Portuguese autonomous regions where not considered.

The total number of population by gender refers to the number of residents, for Continental Portugal, according to the Portuguese 2021 census data. With the total population being $9,857,593$ people (link3). The number of individuals for each age group corresponds to the annual mean resident population by age group, according to the provisional resident population indicator, obtained from the 2021 census. The sum of the population by group is 10298252 , being slightly lower that the, more up to date, total population relative to the 2021 preliminary census data.

The Fatalities corresponds to the date of discharge for patients that died. With the fatality rate being calculated as:

$$
\text { Fatality rate }=\frac{\text { Fatalities }}{\text { Entries }} * 100 \%,
$$

and the percentage of ICU patients as:

$$
\text { Percentage of ICU patients }=\frac{\text { ICU Entries }}{\text { Total Entries }} * 100 \% .
$$


medRxiv preprint doi: https://doi.org/10.1101/2022.03.03.22271349; this version posted March 6, 2022. The copyright holder for this preprint (which was not certified by peer review) is the author/funder, who has granted medRxiv a license to display the preprint in perpetuity. It is made available under a CC-BY-NC 4.0 International license .

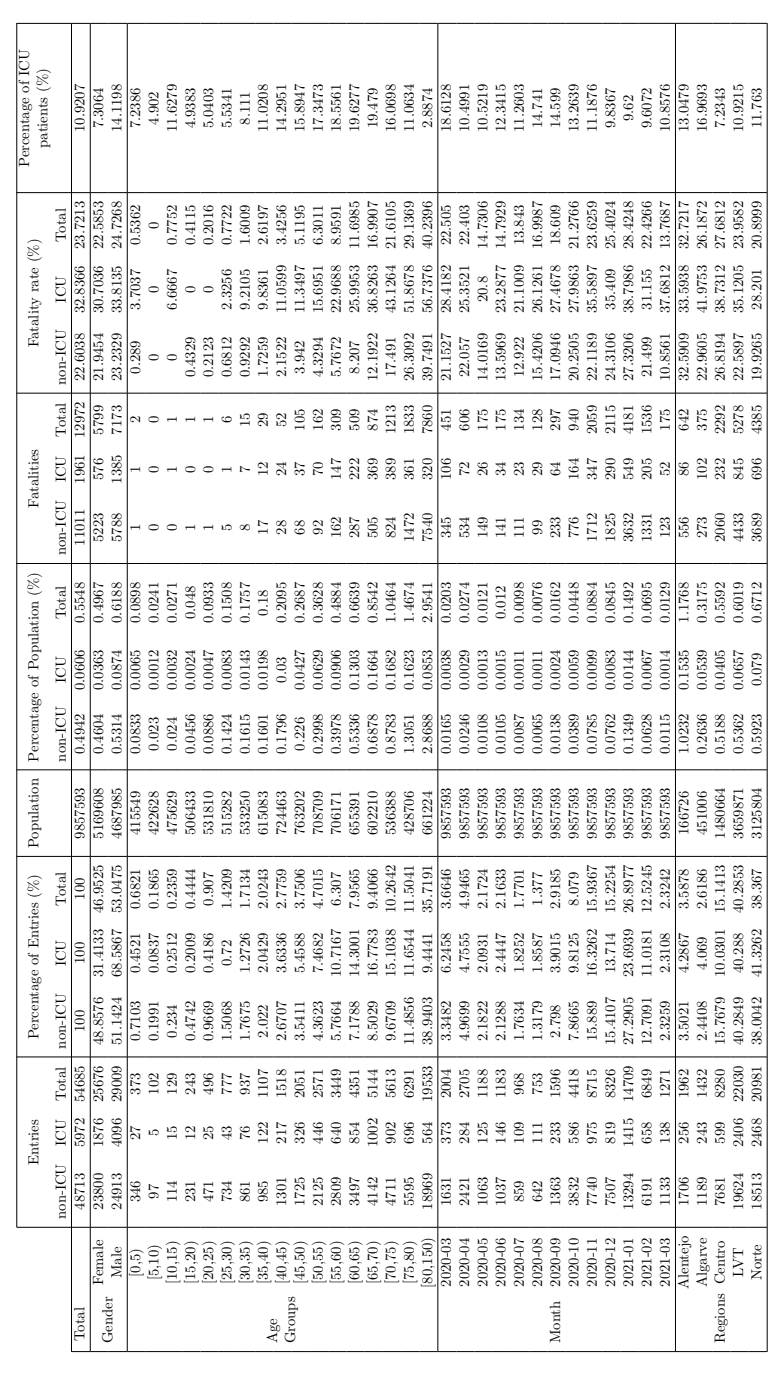


medRxiv preprint doi: https://doi.org/10.1101/2022.03.03.22271349; this version posted March 6, 2022. The copyright holder for this preprint (which was not certified by peer review) is the author/funder, who has granted medRxiv a license to display the preprint in perpetuity.

It is made available under a CC-BY-NC 4.0 International license .

COVID-19 Hospitalisation in Portugal, the first year: Results from hospital discharge data 23

Table 4: Table with daily admissions (Part I)

\begin{tabular}{|c|c|c|c|c|c|}
\hline Date & Entries & Discharges & $\begin{array}{l}\text { non-ICU } \\
\text { entries }\end{array}$ & $\begin{array}{l}\text { non-ICU } \\
\text { dis- } \\
\text { charges }\end{array}$ & $\begin{array}{l}\text { Non-ICU } \\
\text { in hospi- } \\
\text { tal }\end{array}$ \\
\hline $2020-03-01$ & 5 & 0 & 5 & 0 & 5 \\
\hline 2020-03-02 & 7 & 0 & 7 & 0 & 12 \\
\hline 2020-03-03 & 12 & 1 & 11 & 1 & 22 \\
\hline 2020-03-04 & 13 & 0 & 12 & 0 & 34 \\
\hline 2020-03-05 & 14 & 0 & 8 & 0 & 42 \\
\hline $2020-03-06$ & 13 & 1 & 13 & 1 & 54 \\
\hline $2020-03-07$ & 16 & 0 & 15 & 0 & 69 \\
\hline $2020-03-08$ & 16 & 1 & 15 & 1 & 83 \\
\hline 2020-03-09 & 18 & 1 & 16 & 1 & 98 \\
\hline $2020-03-10$ & 20 & 0 & 16 & 0 & 114 \\
\hline $2020-03-11$ & 25 & 2 & 20 & 2 & 132 \\
\hline $2020-03-12$ & 23 & 9 & 19 & 9 & 142 \\
\hline $2020-03-13$ & 29 & 11 & 26 & 11 & 157 \\
\hline 2020-03-14 & 31 & 4 & 25 & 4 & 178 \\
\hline $2020-03-15$ & 26 & 3 & 15 & 3 & 190 \\
\hline $2020-03-16$ & 37 & 7 & 30 & 6 & 214 \\
\hline $2020-03-17$ & 44 & 10 & 33 & 9 & 238 \\
\hline 2020-03-18 & 53 & 9 & 40 & 8 & 270 \\
\hline 2020-03-19 & 65 & 14 & 51 & 13 & 308 \\
\hline $2020-03-20$ & 68 & 20 & 49 & 19 & 338 \\
\hline 2020-03-21 & 95 & 19 & 76 & 19 & 395 \\
\hline $2020-03-22$ & 97 & 12 & 78 & 12 & 461 \\
\hline $2020-03-23$ & 105 & 19 & 85 & 18 & 528 \\
\hline $2020-03-24$ & 119 & 31 & 92 & 26 & 594 \\
\hline $2020-03-25$ & 142 & 31 & 116 & 28 & 682 \\
\hline $2020-03-26$ & 136 & 30 & 113 & 27 & 768 \\
\hline $2020-03-27$ & 145 & 53 & 116 & 45 & 839 \\
\hline $2020-03-28$ & 172 & 41 & 145 & 39 & 945 \\
\hline $2020-03-29$ & 131 & 38 & 109 & 35 & 1019 \\
\hline $2020-03-30$ & 157 & 72 & 136 & 65 & 1090 \\
\hline $2020-03-31$ & 170 & 85 & 139 & 80 & 1149 \\
\hline 2020-04-01 & 152 & 76 & 137 & 70 & 1216 \\
\hline 2020-04-02 & 163 & 92 & 138 & 72 & 1282 \\
\hline 2020-04-03 & 129 & 97 & 109 & 84 & 1307 \\
\hline $2020-04-04$ & 134 & 66 & 115 & 60 & 1362 \\
\hline 2020-04-05 & 127 & 60 & 118 & 51 & 1429 \\
\hline $2020-04-06$ & 125 & 110 & 113 & 98 & 1444 \\
\hline $2020-04-07$ & 114 & 137 & 105 & 124 & 1425 \\
\hline $2020-04-08$ & 122 & 120 & 111 & 112 & 1424 \\
\hline 2020-04-09 & 88 & 97 & 77 & 86 & 1415 \\
\hline $2020-04-10$ & 107 & 102 & 94 & 93 & 1416 \\
\hline $2020-04-11$ & 102 & 70 & 92 & 60 & 1448 \\
\hline $2020-04-12$ & 90 & 58 & 79 & 49 & 1478 \\
\hline $2020-04-13$ & 90 & 109 & 80 & 96 & 1462 \\
\hline 2020-04-14 & 116 & 128 & 107 & 113 & 1456 \\
\hline 2020-04-15 & 103 & 125 & 96 & 110 & 1442 \\
\hline 2020-04-16 & 94 & 111 & 87 & 97 & 1432 \\
\hline $2020-04-17$ & 106 & 129 & 94 & 113 & 1413 \\
\hline 2020-04-18 & 75 & 72 & 67 & 60 & 1420 \\
\hline 2020-04-19 & 55 & 66 & 51 & 59 & 1412 \\
\hline $2020-04-20$ & 80 & 113 & 73 & 96 & 1389 \\
\hline 2020-04-21 & 61 & 99 & 55 & 92 & 1352 \\
\hline $2020-04-22$ & 58 & 105 & 52 & 89 & 1315 \\
\hline $2020-04-23$ & 62 & 98 & 55 & 86 & 1284 \\
\hline $2020-04-24$ & 67 & 110 & 57 & 93 & 1248 \\
\hline $2020-04-25$ & 61 & 55 & 53 & 49 & 1252 \\
\hline $2020-04-26$ & 47 & 52 & 45 & 46 & 1251 \\
\hline $2020-04-27$ & 42 & 93 & 38 & 83 & 1206 \\
\hline $2020-04-28$ & 38 & 99 & 36 & 83 & 1159 \\
\hline 2020-04-29 & 45 & 85 & 42 & 76 & 1125 \\
\hline 2020-04-30 & 52 & 85 & 45 & 79 & 1091 \\
\hline $2020-05-01$ & 40 & 60 & 36 & 51 & 1076 \\
\hline 2020-05-02 & 40 & 52 & 36 & 45 & 1067 \\
\hline 2020-05-03 & 34 & 40 & 33 & 40 & 1060 \\
\hline $2020-05-04$ & 49 & 104 & 41 & 91 & 1010 \\
\hline $2020-05-05$ & 33 & 106 & 27 & 91 & 946 \\
\hline $2020-05-06$ & 41 & 86 & 39 & 69 & 916 \\
\hline $2020-05-07$ & 52 & 66 & 51 & 61 & 906 \\
\hline $2020-05-08$ & 29 & 88 & 25 & 68 & 863 \\
\hline 2020-05-09 & 39 & 40 & 33 & 34 & 862 \\
\hline $2020-05-10$ & 34 & 26 & 30 & 22 & 870 \\
\hline $2020-05-11$ & 34 & 83 & 25 & 75 & 820 \\
\hline $2020-05-12$ & 38 & 67 & 35 & 56 & 799 \\
\hline $2020-05-13$ & 50 & 81 & 41 & 70 & 770 \\
\hline $2020-05-14$ & 49 & 73 & 46 & 60 & 756 \\
\hline $2020-05-15$ & 48 & 56 & 44 & 50 & 750 \\
\hline $2020-05-16$ & 37 & 38 & 31 & 34 & 747 \\
\hline $2020-05-17$ & 33 & 22 & 30 & 21 & 756 \\
\hline $2020-05-18$ & 25 & 74 & 24 & 66 & 714 \\
\hline $2020-05-19$ & 31 & 65 & 27 & 55 & 686 \\
\hline $2020-05-20$ & 44 & 72 & 39 & 62 & 663 \\
\hline $2020-05-21$ & 21 & 42 & 20 & 35 & 648 \\
\hline $2020-05-22$ & 36 & 83 & 34 & 70 & 612 \\
\hline $2020-05-23$ & 37 & 35 & 31 & 30 & 613 \\
\hline $2020-05-24$ & 34 & 15 & 28 & 12 & 629 \\
\hline $2020-05-25$ & 33 & 57 & 30 & 46 & 613 \\
\hline $2020-05-26$ & 39 & 46 & 37 & 37 & 613 \\
\hline $2020-05-27$ & 66 & 66 & 61 & 62 & 612 \\
\hline $2020-05-28$ & 55 & 60 & 49 & 55 & 606 \\
\hline $2020-05-29$ & 38 & 73 & 36 & 65 & 577 \\
\hline $2020-05-30$ & 33 & 25 & 30 & 25 & 582 \\
\hline $2020-05-31$ & 16 & 18 & 14 & 18 & 578 \\
\hline
\end{tabular}


medRxiv preprint doi: https://doi.org/10.1101/2022.03.03.22271349; this version posted March 6, 2022. The copyright holder for this preprint (which was not certified by peer review) is the author/funder, who has granted medRxiv a license to display the preprint in perpetuity.

It is made available under a CC-BY-NC 4.0 International license .

Table 5: Table with daily admissions (Part II)

\begin{tabular}{|c|c|c|c|c|c|}
\hline Date & Entries & Discharges & $\begin{array}{l}\text { non-ICU } \\
\text { entries }\end{array}$ & $\begin{array}{l}\text { non-ICU } \\
\text { dis- } \\
\text { charges }\end{array}$ & $\begin{array}{l}\text { Non-ICU } \\
\text { in hospi- } \\
\text { tal }\end{array}$ \\
\hline $2020-06-01$ & 49 & 54 & 41 & 47 & 572 \\
\hline 2020-06-02 & 40 & 45 & 36 & 40 & 568 \\
\hline 2020-06-03 & 42 & 51 & 38 & 44 & 562 \\
\hline $2020-06-04$ & 40 & 56 & 38 & 49 & 551 \\
\hline 2020-06-05 & 35 & 65 & 31 & 56 & 526 \\
\hline $2020-06-06$ & 27 & 32 & 26 & 30 & 522 \\
\hline $2020-06-07$ & 28 & 18 & 21 & 17 & 526 \\
\hline $2020-06-08$ & 35 & 43 & 29 & 39 & 516 \\
\hline 2020-06-09 & 37 & 45 & 33 & 43 & 506 \\
\hline $2020-06-10$ & 26 & 31 & 25 & 26 & 505 \\
\hline $2020-06-11$ & 35 & 7 & 29 & 7 & 527 \\
\hline $2020-06-12$ & 40 & 64 & 36 & 58 & 505 \\
\hline $2020-06-13$ & 39 & 22 & 35 & 20 & 520 \\
\hline $2020-06-14$ & 23 & 16 & 21 & 15 & 526 \\
\hline $2020-06-15$ & 51 & 63 & 43 & 50 & 519 \\
\hline $2020-06-16$ & 29 & 41 & 26 & 38 & 507 \\
\hline $2020-06-17$ & 36 & 57 & 31 & 45 & 493 \\
\hline $2020-06-18$ & 46 & 46 & 42 & 40 & 495 \\
\hline $2020-06-19$ & 46 & 62 & 42 & 51 & 486 \\
\hline $2020-06-20$ & 47 & 23 & 41 & 19 & 508 \\
\hline $2020-06-21$ & 39 & 9 & 34 & 8 & 534 \\
\hline $2020-06-22$ & 53 & 64 & 48 & 53 & 529 \\
\hline $2020-06-23$ & 53 & 53 & 47 & 46 & 530 \\
\hline $2020-06-24$ & 53 & 42 & 45 & 39 & 536 \\
\hline $2020-06-25$ & 46 & 51 & 39 & 47 & 528 \\
\hline $2020-06-26$ & 45 & 52 & 38 & 45 & 521 \\
\hline $2020-06-27$ & 38 & 25 & 35 & 23 & 533 \\
\hline $2020-06-28$ & 37 & 13 & 31 & 12 & 552 \\
\hline $2020-06-29$ & 37 & 62 & 29 & 54 & 527 \\
\hline $2020-06-30$ & 31 & 36 & 27 & 32 & 522 \\
\hline $2020-07-01$ & 39 & 59 & 34 & 50 & 506 \\
\hline $2020-07-02$ & 33 & 46 & 31 & 42 & 495 \\
\hline $2020-07-03$ & 51 & 65 & 45 & 61 & 479 \\
\hline $2020-07-04$ & 37 & 23 & 33 & 18 & 494 \\
\hline $2020-07-05$ & 37 & 22 & 31 & 19 & 506 \\
\hline $2020-07-06$ & 44 & 59 & 39 & 54 & 491 \\
\hline $2020-07-07$ & 39 & 37 & 35 & 31 & 495 \\
\hline $2020-07-08$ & 40 & 58 & 37 & 48 & 484 \\
\hline $2020-07-09$ & 35 & 52 & 32 & 46 & 470 \\
\hline $2020-07-10$ & 40 & 45 & 34 & 38 & 466 \\
\hline $2020-07-11$ & 23 & 25 & 23 & 18 & 471 \\
\hline $2020-07-12$ & 25 & 8 & 21 & 8 & 484 \\
\hline $2020-07-13$ & 36 & 38 & 32 & 29 & 487 \\
\hline $2020-07-14$ & 30 & 42 & 29 & 39 & 477 \\
\hline $2020-07-15$ & 36 & 39 & 30 & 34 & 473 \\
\hline $2020-07-16$ & 29 & 37 & 25 & 31 & 467 \\
\hline $2020-07-17$ & 30 & 51 & 24 & 42 & 449 \\
\hline $2020-07-18$ & 26 & 20 & 24 & 17 & 456 \\
\hline 2020-07-19 & 28 & 13 & 24 & 12 & 468 \\
\hline $2020-07-20$ & 32 & 44 & 27 & 39 & 456 \\
\hline $2020-07-21$ & 29 & 39 & 27 & 31 & 452 \\
\hline $2020-07-22$ & 27 & 33 & 25 & 30 & 447 \\
\hline $2020-07-23$ & 33 & 52 & 29 & 43 & 433 \\
\hline $2020-07-24$ & 32 & 47 & 28 & 39 & 422 \\
\hline $2020-07-25$ & 24 & 18 & 20 & 16 & 426 \\
\hline $2020-07-26$ & 28 & 12 & 28 & 10 & 444 \\
\hline $2020-07-27$ & 19 & 34 & 18 & 32 & 430 \\
\hline $2020-07-28$ & 23 & 30 & 19 & 26 & 423 \\
\hline $2020-07-29$ & 22 & 35 & 19 & 30 & 412 \\
\hline $2020-07-30$ & 21 & 42 & 18 & 36 & 394 \\
\hline $2020-07-31$ & 20 & 58 & 18 & 45 & 367 \\
\hline $2020-08-01$ & 22 & 9 & 18 & 9 & 376 \\
\hline $2020-08-02$ & 22 & 6 & 21 & 4 & 393 \\
\hline $2020-08-03$ & 15 & 28 & 12 & 24 & 381 \\
\hline $2020-08-04$ & 16 & 29 & 13 & 26 & 368 \\
\hline $2020-08-05$ & 20 & 27 & 18 & 23 & 363 \\
\hline $2020-08-06$ & 21 & 32 & 19 & 27 & 355 \\
\hline $2020-08-07$ & 43 & 49 & 42 & 41 & 356 \\
\hline $2020-08-08$ & 23 & 16 & 21 & 15 & 362 \\
\hline $2020-08-09$ & 24 & 12 & 21 & 10 & 373 \\
\hline $2020-08-10$ & 29 & 37 & 24 & 36 & 361 \\
\hline $2020-08-11$ & 29 & 19 & 25 & 17 & 369 \\
\hline $2020-08-12$ & 16 & 25 & 15 & 20 & 364 \\
\hline $2020-08-13$ & 13 & 27 & 9 & 22 & 351 \\
\hline $2020-08-14$ & 18 & 27 & 15 & 24 & 342 \\
\hline $2020-08-15$ & 25 & 13 & 18 & 12 & 348 \\
\hline $2020-08-16$ & 20 & 6 & 18 & 6 & 360 \\
\hline $2020-08-17$ & 27 & 33 & 22 & 25 & 357 \\
\hline $2020-08-18$ & 20 & 28 & 20 & 26 & 351 \\
\hline $2020-08-19$ & 29 & 29 & 21 & 25 & 347 \\
\hline $2020-08-20$ & 25 & 32 & 22 & 30 & 339 \\
\hline $2020-08-21$ & 22 & 14 & 19 & 12 & 346 \\
\hline $2020-08-22$ & 20 & 12 & 18 & 11 & 353 \\
\hline $2020-08-23$ & 25 & 17 & 18 & 14 & 357 \\
\hline $2020-08-24$ & 23 & 24 & 20 & 19 & 358 \\
\hline $2020-08-25$ & 25 & 34 & 21 & 30 & 349 \\
\hline $2020-08-26$ & 31 & 37 & 27 & 35 & 341 \\
\hline $2020-08-27$ & 36 & 25 & 28 & 19 & 350 \\
\hline $2020-08-28$ & 32 & 42 & 27 & 35 & 342 \\
\hline 2020-08-29 & 30 & 12 & 26 & 12 & 356 \\
\hline $2020-08-30$ & 23 & 12 & 20 & 12 & 364 \\
\hline $2020-08-31$ & 29 & 30 & 24 & 25 & 363 \\
\hline
\end{tabular}


medRxiv preprint doi: https://doi.org/10.1101/2022.03.03.22271349; this version posted March 6, 2022. The copyright holder for this preprint (which was not certified by peer review) is the author/funder, who has granted medRxiv a license to display the preprint in perpetuity.

It is made available under a CC-BY-NC 4.0 International license .

COVID-19 Hospitalisation in Portugal, the first year: Results from hospital discharge data 25

Table 6: Table with daily admissions (Pare III)

\begin{tabular}{|c|c|c|c|c|c|c|}
\hline Date & Entries & Discharges & $\begin{array}{l}\text { non-ICU } \\
\text { entries }\end{array}$ & $\begin{array}{l}\text { non-ICU } \\
\text { dis- } \\
\text { charges }\end{array}$ & $\begin{array}{l}\text { Non-ICU } \\
\text { in hospi- } \\
\text { tal }\end{array}$ & $\begin{array}{l}\text { ICU en- } \\
\text { tries }\end{array}$ \\
\hline $2020-09-01$ & 34 & 23 & 32 & 16 & 379 & 2 \\
\hline 2020-09-02 & 44 & 29 & 35 & 25 & 389 & 9 \\
\hline 2020-09-03 & 47 & 38 & 39 & 36 & 392 & 8 \\
\hline 2020-09-04 & 37 & 29 & 30 & 25 & 397 & 7 \\
\hline 2020-09-05 & 43 & 16 & 39 & 15 & 421 & 4 \\
\hline 2020-09-06 & 38 & 10 & 28 & 9 & 440 & 10 \\
\hline $2020-09-07$ & 47 & 37 & 46 & 31 & 455 & 1 \\
\hline 2020-09-08 & 46 & 38 & 35 & 30 & 460 & 11 \\
\hline 2020-09-09 & 50 & 24 & 44 & 24 & 480 & 6 \\
\hline 2020-09-10 & 49 & 35 & 42 & 31 & 491 & 7 \\
\hline 2020-09-11 & 53 & 33 & 48 & 29 & 510 & 5 \\
\hline 2020-09-12 & 46 & 24 & 39 & 23 & 526 & 7 \\
\hline $2020-09-13$ & 49 & 11 & 41 & 10 & 557 & 8 \\
\hline 2020-09-14 & 49 & 45 & 39 & 38 & 558 & 10 \\
\hline 2020-09-15 & 51 & 42 & 42 & 37 & 563 & 9 \\
\hline $2020-09-16$ & 51 & 54 & 49 & 46 & 566 & 2 \\
\hline $2020-09-17$ & 49 & 44 & 42 & 41 & 567 & 7 \\
\hline 2020-09-18 & 62 & 48 & 55 & 43 & 579 & 7 \\
\hline 2020-09-19 & 55 & 31 & 49 & 27 & 601 & 6 \\
\hline $2020-09-20$ & 49 & 19 & 41 & 15 & 627 & 8 \\
\hline 2020-09-21 & 67 & 47 & 62 & 41 & 648 & 5 \\
\hline $2020-09-22$ & 68 & 53 & 58 & 47 & 659 & 10 \\
\hline $2020-09-23$ & 76 & 44 & 64 & 41 & 682 & 12 \\
\hline $2020-09-24$ & 71 & 36 & 59 & 34 & 707 & 12 \\
\hline $2020-09-25$ & 60 & 70 & 51 & 63 & 695 & 9 \\
\hline $2020-09-26$ & 52 & 26 & 44 & 25 & 714 & 8 \\
\hline $2020-09-27$ & 65 & 21 & 53 & 17 & 750 & 12 \\
\hline $2020-09-28$ & 54 & 42 & 46 & 37 & 759 & 8 \\
\hline 2020-09-29 & 65 & 65 & 51 & 57 & 753 & 14 \\
\hline $2020-09-30$ & 69 & 50 & 60 & 46 & 767 & 9 \\
\hline 2020-10-01 & 68 & 59 & 58 & 50 & 775 & 10 \\
\hline $2020-10-02$ & 64 & 65 & 53 & 58 & 770 & 11 \\
\hline $2020-10-03$ & 65 & 43 & 61 & 39 & 792 & 4 \\
\hline $2020-10-04$ & 76 & 32 & 69 & 30 & 831 & 7 \\
\hline $2020-10-05$ & 91 & 37 & 78 & 28 & 881 & 13 \\
\hline $2020-10-06$ & 96 & 52 & 81 & 46 & 916 & 15 \\
\hline $2020-10-07$ & 113 & 78 & 97 & 71 & 942 & 16 \\
\hline $2020-10-08$ & 84 & 77 & 73 & 69 & 946 & 11 \\
\hline $2020-10-09$ & 122 & 91 & 110 & 79 & 977 & 12 \\
\hline $2020-10-10$ & 87 & 31 & 79 & 25 & 1031 & 8 \\
\hline $2020-10-11$ & 74 & 31 & 57 & 25 & 1063 & 17 \\
\hline $2020-10-12$ & 98 & 86 & 81 & 73 & 1071 & 17 \\
\hline $2020-10-13$ & 105 & 80 & 95 & 74 & 1092 & 10 \\
\hline $2020-10-14$ & 129 & 109 & 112 & 93 & 1111 & 17 \\
\hline $2020-10-15$ & 127 & 125 & 109 & 110 & 1110 & 18 \\
\hline $2020-10-16$ & 132 & 101 & 115 & 88 & 1137 & 17 \\
\hline $2020-10-17$ & 131 & 46 & 110 & 41 & 1206 & 21 \\
\hline $2020-10-18$ & 139 & 37 & 118 & 33 & 1291 & 21 \\
\hline $2020-10-19$ & 156 & 123 & 128 & 111 & 1308 & 28 \\
\hline $2020-10-20$ & 183 & 114 & 160 & 103 & 1365 & 23 \\
\hline $2020-10-21$ & 174 & 114 & 148 & 102 & 1411 & 26 \\
\hline $2020-10-22$ & 189 & 138 & 166 & 119 & 1458 & 23 \\
\hline $2020-10-23$ & 203 & 144 & 185 & 122 & 1521 & 18 \\
\hline $2020-10-24$ & 184 & 72 & 155 & 65 & 1611 & 29 \\
\hline $2020-10-25$ & 151 & 57 & 135 & 52 & 1694 & 16 \\
\hline $2020-10-26$ & 240 & 165 & 206 & 152 & 1748 & 34 \\
\hline $2020-10-27$ & 198 & 175 & 176 & 154 & 1770 & 22 \\
\hline $2020-10-28$ & 208 & 172 & 176 & 156 & 1790 & 32 \\
\hline 2020-10-29 & 222 & 182 & 192 & 164 & 1818 & 30 \\
\hline $2020-10-30$ & 260 & 211 & 228 & 196 & 1850 & 32 \\
\hline $2020-10-31$ & 249 & 94 & 221 & 83 & 1988 & 28 \\
\hline 2020-11-01 & 240 & 82 & 199 & 69 & 2118 & 41 \\
\hline $2020-11-02$ & 226 & 200 & 198 & 184 & 2132 & 28 \\
\hline $2020-11-03$ & 234 & 250 & 212 & 216 & 2128 & 22 \\
\hline $2020-11-04$ & 310 & 251 & 278 & 235 & 2171 & 32 \\
\hline $2020-11-05$ & 330 & 258 & 289 & 230 & 2230 & 41 \\
\hline $2020-11-06$ & 262 & 250 & 232 & 228 & 2234 & 30 \\
\hline $2020-11-07$ & 281 & 102 & 244 & 96 & 2382 & 37 \\
\hline $2020-11-08$ & 251 & 112 & 216 & 101 & 2497 & 35 \\
\hline 2020-11-09 & 272 & 256 & 252 & 224 & 2525 & 20 \\
\hline $2020-11-10$ & 262 & 277 & 234 & 249 & 2510 & 28 \\
\hline 2020-11-11 & 344 & 283 & 313 & 254 & 2569 & 31 \\
\hline 2020-11-12 & 299 & 287 & 265 & 258 & 2576 & 34 \\
\hline $2020-11-13$ & 293 & 284 & 263 & 260 & 2579 & 30 \\
\hline $2020-11-14$ & 318 & 127 & 286 & 104 & 2761 & 32 \\
\hline $2020-11-15$ & 262 & 155 & 223 & 139 & 2845 & 39 \\
\hline $2020-11-16$ & 292 & 310 & 260 & 289 & 2816 & 32 \\
\hline $2020-11-17$ & 289 & 331 & 262 & 298 & 2780 & 27 \\
\hline $2020-11-18$ & 319 & 303 & 270 & 280 & 2770 & 49 \\
\hline 2020-11-19 & 324 & 276 & 291 & 248 & 2813 & 33 \\
\hline $2020-11-20$ & 337 & 349 & 303 & 319 & 2797 & 34 \\
\hline $2020-11-21$ & 289 & 125 & 271 & 112 & 2956 & 18 \\
\hline $2020-11-22$ & 306 & 144 & 254 & 126 & 3084 & 52 \\
\hline $2020-11-23$ & 289 & 323 & 261 & 297 & 3048 & 28 \\
\hline $2020-11-24$ & 308 & 314 & 279 & 287 & 3040 & 29 \\
\hline $2020-11-25$ & 320 & 313 & 281 & 283 & 3038 & 39 \\
\hline $2020-11-26$ & 318 & 288 & 285 & 265 & 3058 & 33 \\
\hline $2020-11-27$ & 302 & 387 & 266 & 341 & 2983 & 36 \\
\hline $2020-11-28$ & 310 & 133 & 273 & 119 & 3137 & 37 \\
\hline 2020-11-29 & 250 & 138 & 228 & 119 & 3246 & 22 \\
\hline $2020-11-30$ & 278 & 363 & 252 & 326 & 3172 & 26 \\
\hline
\end{tabular}


medRxiv preprint doi: https://doi.org/10.1101/2022.03.03.22271349; this version posted March 6, 2022. The copyright holder for this preprint (which was not certified by peer review) is the author/funder, who has granted medRxiv a license to display the preprint in perpetuity.

It is made available under a CC-BY-NC 4.0 International license .

Table 7: Table with dmissions aggregataed by day (Part IV)

\begin{tabular}{|c|c|c|c|c|c|c|c|}
\hline Date & Entries & Discharges & $\begin{array}{l}\text { non-ICU } \\
\text { entries }\end{array}$ & $\begin{array}{l}\text { non-ICU } \\
\text { dis- } \\
\text { charges }\end{array}$ & $\begin{array}{l}\text { Non-ICU } \\
\text { in hospi- } \\
\text { tal }\end{array}$ & $\begin{array}{l}\text { ICU } \\
\text { tries }\end{array}$ & en- \\
\hline $2020-12-01$ & 293 & 156 & 256 & 146 & 3282 & 37 & \\
\hline $2020-12-02$ & 290 & 349 & 262 & 312 & 3232 & 28 & \\
\hline $2020-12-03$ & 273 & 366 & 246 & 321 & 3157 & 27 & \\
\hline $2020-12-04$ & 334 & 372 & 301 & 339 & 3119 & 33 & \\
\hline $2020-12-05$ & 259 & 168 & 231 & 152 & 3198 & 28 & \\
\hline $2020-12-06$ & 255 & 148 & 235 & 132 & 3301 & 20 & \\
\hline $2020-12-07$ & 268 & 397 & 249 & 347 & 3203 & 19 & \\
\hline $2020-12-08$ & 266 & 168 & 234 & 151 & 3286 & 32 & \\
\hline 2020-12-09 & 281 & 394 & 254 & 356 & 3184 & 27 & \\
\hline $2020-12-10$ & 236 & 356 & 209 & 323 & 3070 & 27 & \\
\hline $2020-12-11$ & 257 & 403 & 234 & 353 & 2951 & 23 & \\
\hline $2020-12-12$ & 249 & 166 & 231 & 150 & 3032 & 18 & \\
\hline $2020-12-13$ & 251 & 134 & 227 & 120 & 3139 & 24 & \\
\hline $2020-12-14$ & 249 & 321 & 224 & 286 & 3077 & 25 & \\
\hline $2020-12-15$ & 273 & 320 & 244 & 288 & 3033 & 29 & \\
\hline $2020-12-16$ & 272 & 317 & 248 & 282 & 2999 & 24 & \\
\hline $2020-12-17$ & 226 & 287 & 200 & 255 & 2944 & 26 & \\
\hline $2020-12-18$ & 268 & 339 & 241 & 308 & 2877 & 27 & \\
\hline $2020-12-19$ & 214 & 154 & 197 & 138 & 2936 & 17 & \\
\hline $2020-12-20$ & 261 & 101 & 232 & 87 & 3081 & 29 & \\
\hline $2020-12-21$ & 226 & 356 & 196 & 317 & 2960 & 30 & \\
\hline $2020-12-22$ & 294 & 372 & 264 & 336 & 2888 & 30 & \\
\hline $2020-12-23$ & 297 & 373 & 279 & 334 & 2833 & 18 & \\
\hline $2020-12-24$ & 232 & 294 & 199 & 267 & 2765 & 33 & \\
\hline $2020-12-25$ & 221 & 111 & 203 & 101 & 2867 & 18 & \\
\hline $2020-12-26$ & 264 & 117 & 231 & 101 & 2997 & 33 & \\
\hline $2020-12-27$ & 250 & 109 & 228 & 95 & 3130 & 22 & \\
\hline $2020-12-28$ & 277 & 295 & 250 & 262 & 3118 & 27 & \\
\hline $2020-12-29$ & 337 & 323 & 306 & 304 & 3120 & 31 & \\
\hline $2020-12-30$ & 291 & 332 & 271 & 293 & 3098 & 20 & \\
\hline $2020-12-31$ & 362 & 366 & 325 & 324 & 3099 & 37 & \\
\hline 2021-01-01 & 302 & 145 & 280 & 133 & 3246 & 22 & \\
\hline 2021-01-02 & 299 & 138 & 272 & 122 & 3396 & 27 & \\
\hline 2021-01-03 & 343 & 118 & 307 & 102 & 3601 & 36 & \\
\hline 2021-01-04 & 335 & 312 & 294 & 280 & 3615 & 41 & \\
\hline 2021-01-05 & 369 & 335 & 324 & 295 & 3644 & 45 & \\
\hline 2021-01-06 & 389 & 331 & 354 & 293 & 3705 & 35 & \\
\hline 2021-01-07 & 409 & 351 & 354 & 318 & 3741 & 55 & \\
\hline 2021-01-08 & 473 & 390 & 418 & 349 & 3810 & 55 & \\
\hline 2021-01-09 & 431 & 166 & 378 & 149 & 4039 & 53 & \\
\hline 2021-01-10 & 389 & 167 & 350 & 149 & 4240 & 39 & \\
\hline 2021-01-11 & 404 & 399 & 356 & 352 & 4244 & 48 & \\
\hline 2021-01-12 & 496 & 414 & 450 & 374 & 4320 & 46 & \\
\hline 2021-01-13 & 472 & 398 & 424 & 352 & 4392 & 48 & \\
\hline 2021-01-14 & 502 & 417 & 461 & 367 & 4486 & 41 & \\
\hline 2021-01-15 & 483 & 494 & 445 & 452 & 4479 & 38 & \\
\hline 2021-01-16 & 476 & 265 & 416 & 242 & 4653 & 60 & \\
\hline 2021-01-17 & 457 & 224 & 415 & 206 & 4862 & 42 & \\
\hline 2021-01-18 & 470 & 467 & 424 & 426 & 4860 & 46 & \\
\hline 2021-01-19 & 557 & 559 & 507 & 513 & 4854 & 50 & \\
\hline 2021-01-20 & 554 & 478 & 506 & 438 & 4922 & 48 & \\
\hline 2021-01-21 & 545 & 461 & 506 & 428 & 5000 & 39 & \\
\hline 2021-01-22 & 560 & 579 & 503 & 534 & 4969 & 57 & \\
\hline 2021-01-23 & 549 & 360 & 507 & 319 & 5157 & 42 & \\
\hline 2021-01-24 & 488 & 279 & 444 & 254 & 5347 & 44 & \\
\hline 2021-01-25 & 596 & 565 & 543 & 518 & 5372 & 53 & \\
\hline 2021-01-26 & 626 & 664 & 574 & 606 & 5340 & 52 & \\
\hline 2021-01-27 & 565 & 653 & 507 & 600 & 5247 & 58 & \\
\hline 2021-01-28 & 590 & 596 & 530 & 549 & 5228 & 60 & \\
\hline 2021-01-29 & 539 & 647 & 492 & 588 & 5132 & 47 & \\
\hline 2021-01-30 & 542 & 397 & 499 & 372 & 5259 & 43 & \\
\hline 2021-01-31 & 499 & 319 & 454 & 290 & 5423 & 45 & \\
\hline 2021-02-01 & 489 & 635 & 441 & 591 & 5273 & 48 & \\
\hline 2021-02-02 & 531 & 615 & 496 & 577 & 5192 & 35 & \\
\hline 2021-02-03 & 515 & 678 & 468 & 630 & 5030 & 47 & \\
\hline 2021-02-04 & 478 & 599 & 440 & 561 & 4909 & 38 & \\
\hline 2021-02-05 & 425 & 697 & 393 & 636 & 4666 & 32 & \\
\hline 2021-02-06 & 387 & 294 & 346 & 276 & 4736 & 41 & \\
\hline 2021-02-07 & 310 & 257 & 279 & 231 & 4784 & 31 & \\
\hline 2021-02-08 & 320 & 598 & 293 & 555 & 4522 & 27 & \\
\hline 2021-02-09 & 354 & 579 & 327 & 532 & 4317 & 27 & \\
\hline 2021-02-10 & 352 & 568 & 301 & 508 & 4110 & 51 & \\
\hline 2021-02-11 & 272 & 523 & 246 & 481 & 3875 & 26 & \\
\hline 2021-02-12 & 272 & 611 & 244 & 543 & 3576 & 28 & \\
\hline 2021-02-13 & 227 & 221 & 210 & 193 & 3593 & 17 & \\
\hline 2021-02-14 & 175 & 165 & 155 & 144 & 3604 & 20 & \\
\hline 2021-02-15 & 181 & 474 & 154 & 423 & 3335 & 27 & \\
\hline 2021-02-16 & 181 & 458 & 165 & 405 & 3095 & 16 & \\
\hline 2021-02-17 & 167 & 416 & 152 & 370 & 2877 & 15 & \\
\hline 2021-02-18 & 151 & 352 & 138 & 314 & 2701 & 13 & \\
\hline 2021-02-19 & 170 & 451 & 150 & 406 & 2445 & 20 & \\
\hline 2021-02-20 & 144 & 120 & 128 & 104 & 2469 & 16 & \\
\hline 2021-02-21 & 97 & 110 & 86 & 94 & 2461 & 11 & \\
\hline 2021-02-22 & 121 & 348 & 109 & 314 & 2256 & 12 & \\
\hline $2021-02-23$ & 105 & 297 & 91 & 257 & 2090 & 14 & \\
\hline 2021-02-24 & 104 & 262 & 96 & 226 & 1960 & 8 & \\
\hline 2021-02-25 & 101 & 265 & 94 & 224 & 1830 & 7 & \\
\hline 2021-02-26 & 80 & 280 & 66 & 237 & 1659 & 14 & \\
\hline 2021-02-27 & 83 & 96 & 72 & 82 & 1649 & 11 & \\
\hline 2021-02-28 & 57 & 60 & 51 & 50 & 1650 & 6 & \\
\hline
\end{tabular}


medRxiv preprint doi: https://doi.org/10.1101/2022.03.03.22271349; this version posted March 6, 2022. The copyright holder for this preprint (which was not certified by peer review) is the author/funder, who has granted medRxiv a license to display the preprint in perpetuity.

It is made available under a CC-BY-NC 4.0 International license.

COVID-19 Hospitalisation in Portugal, the first year: Results from hospital discharge data 27

Table 8: Table with daily admissions (Part 5)

\begin{tabular}{|c|c|c|c|c|c|c|c|c|c|c|c|c|}
\hline Date & Entries & Discharges & $\begin{array}{l}\text { non-ICU } \\
\text { entries }\end{array}$ & $\begin{array}{l}\text { non-ICU } \\
\text { dis- } \\
\text { charges }\end{array}$ & $\begin{array}{l}\text { Non-ICU } \\
\text { in hospi- } \\
\text { tal }\end{array}$ & $\begin{array}{l}\text { ICU en- } \\
\text { tries }\end{array}$ & ICU exits & $\begin{array}{l}\text { ICU in } \\
\text { hospital }\end{array}$ & $\begin{array}{l}\text { Non-ICU } \\
\text { deaths }\end{array}$ & $\begin{array}{l}\text { ICU } \\
\text { deaths }\end{array}$ & $\begin{array}{l}\text { sum } \\
\text { non-ICU } \\
\text { deaths }\end{array}$ & $\begin{array}{l}\text { sum ICU } \\
\text { deaths }\end{array}$ \\
\hline 2021-03-01 & 86 & 244 & 80 & 203 & 1527 & 6 & 41 & 516 & 23 & 11 & 10665 & 1786 \\
\hline 2021-03-02 & 70 & 200 & 58 & 172 & 1413 & 12 & 28 & 500 & 30 & 5 & 10695 & 1791 \\
\hline 2021-03-03 & 71 & 181 & 63 & 156 & 1320 & 8 & 25 & 483 & 22 & 4 & 10717 & 1795 \\
\hline 2021-03-04 & 67 & 176 & 57 & 153 & 1224 & 10 & 23 & 470 & 24 & 5 & 10741 & 1800 \\
\hline 2021-03-05 & 68 & 209 & 64 & 180 & 1108 & 4 & 29 & 445 & 18 & 5 & 10759 & 1805 \\
\hline 2021-03-06 & 60 & 53 & 55 & 45 & 1118 & 5 & 8 & 442 & 19 & 6 & 10778 & 1811 \\
\hline 2021-03-07 & 38 & 41 & 35 & 32 & 1121 & 3 & 9 & 436 & 17 & 5 & 10795 & 1816 \\
\hline 2021-03-08 & 45 & 184 & 40 & 155 & 1006 & 5 & 29 & 412 & 17 & 11 & 10812 & 1827 \\
\hline 2021-03-09 & 52 & 149 & 43 & 123 & 926 & 9 & 26 & 395 & 13 & 6 & 10825 & 1833 \\
\hline 2021-03-10 & 50 & 127 & 47 & 109 & 864 & 3 & 18 & 380 & 12 & 3 & 10837 & 1836 \\
\hline 2021-03-11 & 41 & 112 & 35 & 91 & 808 & 6 & 21 & 365 & 10 & 4 & 10847 & 1840 \\
\hline 2021-03-12 & 33 & 132 & 28 & 111 & 725 & 5 & 21 & 349 & 16 & 3 & 10863 & 1843 \\
\hline 2021-03-13 & 33 & 39 & 30 & 32 & 723 & 3 & 7 & 345 & 7 & 7 & 10870 & 1850 \\
\hline 2021-03-14 & 27 & 27 & 25 & 22 & 726 & 2 & 5 & 342 & 11 & 4 & 10881 & 1854 \\
\hline 2021-03-15 & 29 & 95 & 28 & 71 & 683 & 1 & 24 & 319 & 6 & 6 & 10887 & 1860 \\
\hline 2021-03-16 & 38 & 111 & 33 & 89 & 627 & 5 & 22 & 302 & 9 & 5 & 10896 & 1865 \\
\hline 2021-03-17 & 41 & 82 & 35 & 65 & 597 & 6 & 17 & 291 & 6 & 7 & 10902 & 1872 \\
\hline 2021-03-18 & 39 & 79 & 37 & 59 & 575 & 2 & 20 & 273 & 6 & 3 & 10908 & 1875 \\
\hline 2021-03-19 & 35 & 100 & 31 & 73 & 533 & 4 & 27 & 250 & 8 & 5 & 10916 & 1880 \\
\hline 2021-03-20 & 24 & 18 & 22 & 11 & 544 & 2 & 7 & 245 & 3 & 3 & 10919 & 1883 \\
\hline 2021-03-21 & 28 & 24 & 24 & 18 & 550 & 4 & 6 & 243 & 6 & 5 & 10925 & 1888 \\
\hline 2021-03-22 & 40 & 76 & 36 & 65 & 521 & 4 & 11 & 236 & 5 & 1 & 10930 & 1889 \\
\hline 2021-03-23 & 37 & 79 & 32 & 57 & 496 & 5 & 22 & 219 & 6 & 7 & 10936 & 1896 \\
\hline 2021-03-24 & 34 & 63 & 31 & 56 & 471 & 3 & 7 & 215 & 5 & 2 & 10941 & 1898 \\
\hline 2021-03-25 & 34 & 60 & 29 & 51 & 449 & 5 & 9 & 211 & 5 & 0 & 10946 & 1898 \\
\hline 2021-03-26 & 32 & 80 & 28 & 62 & 415 & 4 & 18 & 197 & 3 & 3 & 10949 & 1901 \\
\hline $2021-03-27$ & 25 & 25 & 22 & 20 & 417 & 3 & 5 & 195 & 4 & 4 & 10953 & 1905 \\
\hline 2021-03-28 & 13 & 21 & 10 & 18 & 409 & 3 & 3 & 195 & 5 & 2 & 10958 & 1907 \\
\hline 2021-03-29 & 22 & 63 & 20 & 56 & 373 & 2 & 7 & 190 & 2 & 1 & 10960 & 1908 \\
\hline 2021-03-30 & 25 & 50 & 23 & 35 & 361 & 2 & 15 & 177 & 4 & 1 & 10964 & 1909 \\
\hline 2021-03-31 & 34 & 61 & 32 & 48 & 345 & 2 & 13 & 166 & 8 & 3 & 10972 & 1912 \\
\hline
\end{tabular}

\section{A.3. Representation problem}

As each entry is only introduced in the database when the patient receives hospital discharged, there is a need to cut some days from the end of the data timeline, to ensure a correct representation of the data. In order to do that we calculated the mean, median and the quantiles for the length of stay, before trimming the data, for either hospitalisation and ICU (table 9).

\begin{tabular}{c|ccccccccc} 
& mean & median & $25 \%$ & $75 \%$ & $90 \%$ & $95 \%$ & $99 \%$ & $\max$ & IQR \\
\hline non-ICU & 12.57 & 8 & 4 & 15 & 27 & 38 & 69 & 348 & 11 \\
ICU & 24.34 & 18 & 11.0 & 30.0 & 50.7 & 67.0 & 114.9 & 372 & 19
\end{tabular}

Table 9: Summary statistics of the LoS before data trimming.

Therefore if we remove the last 63 days from the data, we ensure that at least $95 \%$ of patients in hospital at any day are present in the data. To facilitate the analysis, instead of removing the last 63 days, we only consider entries with date of entry until 31 of March 2021. Due to the low numbers of entries, dates before 1 of March 2020 were removed. The first case of COVID-19 in Portugal was confirmed by the Portuguese authorities at March 2nd 2020, but a couple of entries with date of entry prior to that date appear in the data, this could be explained by in hospital infections. As a consequence from the original 55827, 1142 entries were removed, being considered a total of 54685 entries. 
João F. Pereira

\section{A.4. Summary statistics}

1 3

The first summary statistics (table 10) related to the length of stay, for either type of hospitalisation was used in figure 1 to plot the violin/box plot and to expands the information visible in the histograms as they are cut at 100 days of length of stay.

\begin{tabular}{c|ccccccccc} 
LoS & mean & median & $25 \%$ & $75 \%$ & $90 \%$ & $95 \%$ & $99 \%$ & $\max$ & IQR \\
\hline Non-ICU & 12.54 & 8 & 4 & 15 & 27 & 38 & 67 & 348 & 11 \\
ICU & 24.31 & 18 & 11.0 & 30.3 & 51.0 & 66.0 & 112.0 & 216 & 19.3
\end{tabular}

Table 10: Summary statistics of the LoS by type of hospitalisation (non-ICU and ICU patients). ference in LoS between groups with different outcome from hospitalisation seems to arise.

\begin{tabular}{cc|ccccccccc} 
& & mean & median & $25 \%$ & $75 \%$ & $90 \%$ & $95 \%$ & $99 \%$ & max & IQR \\
\hline \multirow{2}{*}{ TuD } & Non-ICU & 11.01 & 7 & 3 & 14 & 24 & 33 & 61 & 228 & 11 \\
& ICU & 20.04 & 16 & 9.0 & 26.0 & 39.0 & 53.0 & 95.4 & 199.0 & 17 \\
\hline \multirow{2}{*}{ TuDisc } & Non-ICU & 12.98 & 9 & 5 & 16 & 28 & 39 & 69 & 348 & 11 \\
& ICU & 26.39 & 19 & 12 & 34 & 56 & 71 & 115 & 216 & 22
\end{tabular}

Table 11: Summary statistics of the length of stay for patients that died (TuD) or where discharged (TuDisc), for either type of hospitalisation (non-ICU and ICU patients).

Tables with the summary statistics for LoS (table 12) and TuD (table 13), in respect to the month (month of entry for LoS and of exit for TuD), age group, gender and region, with violin/box plots build from LoS and TuD in figure 14.

Table 12: Summary statistics of the LoS, by type of hospitalisation (non-ICU and ICU), entry month, age group, gender and region.

\begin{tabular}{|c|c|c|c|c|c|c|c|c|c|c|c|}
\hline Variable & Group & Local & median & mean & $\mathrm{sd}$ & $25 \%$ & $75 \%$ & $90 \%$ & $95 \%$ & $\operatorname{Max}$ & IQR \\
\hline \multirow{17}{*}{ Month } & \multirow{2}{*}{ 2020-03 } & non-ICU & 12.00 & 19.70 & 23.28 & 6.00 & 25.00 & 46.00 & 63.00 & 348.00 & 19.00 \\
\hline & & $\mathrm{ICU}$ & 24.00 & 32.43 & 29.59 & 13.00 & 40.00 & 65.80 & 92.40 & 202.00 & 27.00 \\
\hline & \multirow[b]{2}{*}{ 2020-04 } & non-ICU & 11.00 & 15.79 & 19.62 & 5.00 & 21.00 & 34.00 & 44.00 & 288.00 & 16.00 \\
\hline & & $\mathrm{ICU}$ & 22.00 & 27.11 & 20.55 & 13.00 & 37.00 & 54.70 & 72.55 & 109.00 & 24.00 \\
\hline & \multirow{2}{*}{ 2020-05 } & non-ICU & 10.00 & 15.49 & 20.68 & 4.00 & 20.00 & 33.80 & 44.00 & 277.00 & 16.00 \\
\hline & & $\mathrm{ICU}$ & 22.00 & 26.26 & 21.71 & 12.00 & 34.00 & 45.00 & 61.40 & 166.00 & 22.00 \\
\hline & \multirow{2}{*}{ 2020-06 } & non-ICU & 9.00 & 14.09 & 17.86 & 4.00 & 17.00 & 31.00 & 44.00 & 165.00 & 13.00 \\
\hline & & ICU & 21.00 & 28.66 & 24.91 & 12.00 & 38.75 & 55.50 & 78.75 & 141.00 & 26.75 \\
\hline & \multirow{2}{*}{ 2020-07 } & non-ICU & 10.00 & 15.61 & 22.11 & 4.50 & 17.00 & 33.00 & 51.10 & 236.00 & 12.50 \\
\hline & & ICU & 17.00 & 27.18 & 35.27 & 9.00 & 30.00 & 61.40 & 72.80 & 216.00 & 21.00 \\
\hline & \multirow{2}{*}{ 2020-08 } & non-ICU & 10.00 & 17.76 & 23.86 & 5.00 & 20.00 & 42.90 & 64.00 & 192.00 & 15.00 \\
\hline & & $\mathrm{ICU}$ & 18.00 & 29.60 & 32.76 & 10.00 & 37.50 & 68.00 & 86.50 & 193.00 & 27.50 \\
\hline & \multirow{2}{*}{ 2020-09 } & non-ICU & 11.00 & 17.12 & 20.79 & 5.00 & 21.00 & 39.00 & 55.90 & 230.00 & 16.00 \\
\hline & & $\mathrm{ICU}$ & 22.00 & 30.08 & 27.08 & 13.00 & 34.00 & 63.60 & 85.00 & 168.00 & 21.00 \\
\hline & \multirow{2}{*}{ 2020-10 } & non-ICU & 9.00 & 13.28 & 15.15 & 5.00 & 16.00 & 28.00 & 41.00 & 214.00 & 11.00 \\
\hline & & $\mathrm{ICU}$ & 17.00 & 24.80 & 23.73 & 11.00 & 30.75 & 53.50 & 69.00 & 163.00 & 19.75 \\
\hline & 2020-11 & non-ICU & 8.00 & 12.24 & 13.30 & 4.00 & 15.00 & 26.00 & 37.00 & 200.00 & 11.00 \\
\hline
\end{tabular}


medRxiv preprint doi: https://doi.org/10.1101/2022.03.03.22271349; this version posted March 6, 2022. The copyright holder for this preprint (which was not certified by peer review) is the author/funder, who has granted medRxiv a license to display the preprint in perpetuity. It is made available under a CC-BY-NC 4.0 International license .

COVID-19 Hospitalisation in Portugal, the first year: Results from hospital discharge data 29

\begin{tabular}{|c|c|c|c|c|c|c|c|c|c|c|c|}
\hline & \multirow{3}{*}{$2020-12$} & $\mathrm{ICU}$ & 18.00 & 24.52 & 22.32 & 10.00 & 31.00 & 52.60 & 68.30 & 200.00 & 21.00 \\
\hline & & non-ICU & 9.00 & 13.14 & 13.25 & 5.00 & 17.00 & 29.00 & 40.00 & 145.00 & 12.00 \\
\hline & & ICU & 18.00 & 22.49 & 17.14 & 11.00 & 30.00 & 45.00 & 58.00 & 116.00 & 19.00 \\
\hline & \multirow{2}{*}{ 2021-01 } & non-ICU & 8.00 & 10.99 & 10.83 & 4.00 & 14.00 & 24.00 & 31.00 & 158.00 & 10.00 \\
\hline & & ICU & 16.00 & 21.64 & 19.11 & 10.00 & 26.00 & 44.60 & 61.00 & 158.00 & 16.00 \\
\hline & \multirow{2}{*}{ 2021-02 } & non-ICU & 7.00 & 9.59 & 8.85 & 4.00 & 12.00 & 20.00 & 26.00 & 97.00 & 8.00 \\
\hline & & ICU & 17.00 & 22.02 & 17.97 & 10.00 & 28.00 & 44.00 & 60.15 & 119.00 & 18.00 \\
\hline & \multirow{2}{*}{ 2021-03 } & non-ICU & 7.00 & 10.07 & 9.54 & 4.00 & 13.00 & 21.00 & 28.40 & 78.00 & 9.00 \\
\hline & & ICU & 17.00 & 19.31 & 13.76 & 10.00 & 25.00 & 38.30 & 48.30 & 75.00 & 15.00 \\
\hline \multirow{34}{*}{$\begin{array}{l}\text { Age } \\
\text { Groups }\end{array}$} & \multirow{2}{*}{0,5} & non-ICU & 3.00 & 6.28 & 11.10 & 1.00 & 6.00 & 13.00 & 20.00 & 101.00 & 5.00 \\
\hline & & $\mathrm{ICU}$ & 15.00 & 33.15 & 45.65 & 6.50 & 36.50 & 87.60 & 111.60 & 200.00 & 30.00 \\
\hline & \multirow{2}{*}{5,10} & non-ICU & 4.00 & 5.91 & 6.27 & 1.00 & 8.00 & 12.40 & 17.20 & 34.00 & 7.00 \\
\hline & & ICU & 16.00 & 16.40 & 15.08 & 6.00 & 19.00 & 31.60 & 35.80 & 40.00 & 13.00 \\
\hline & \multirow{2}{*}{10,15} & non-ICU & 3.00 & 7.13 & 9.79 & 1.25 & 9.00 & 18.40 & 30.00 & 47.00 & 7.75 \\
\hline & & ICU & 10.00 & 10.87 & 6.79 & 6.50 & 14.50 & 20.20 & 21.90 & 24.00 & 8.00 \\
\hline & \multirow{2}{*}{15,20} & non-ICU & 3.00 & 7.96 & 19.75 & 2.00 & 7.00 & 17.00 & 29.50 & 277.00 & 5.00 \\
\hline & & ICU & 11.50 & 20.42 & 21.08 & 9.75 & 17.00 & 47.30 & 61.70 & 76.00 & 7.25 \\
\hline & \multirow{2}{*}{20,25} & non-ICU & 4.00 & 7.08 & 13.05 & 2.00 & 7.00 & 15.00 & 26.00 & 225.00 & 5.00 \\
\hline & & $\mathrm{ICU}$ & 13.00 & 18.64 & 18.09 & 9.00 & 26.00 & 31.00 & 39.80 & 89.00 & 17.00 \\
\hline & \multirow[b]{2}{*}{25,30} & non-ICU & 3.00 & 7.49 & 13.90 & 2.00 & 7.00 & 18.00 & 28.00 & 288.00 & 5.00 \\
\hline & & ICU & 13.00 & 20.95 & 21.04 & 8.50 & 27.00 & 41.80 & 56.60 & 101.00 & 18.50 \\
\hline & \multirow{2}{*}{30,35} & non-ICU & 4.00 & 7.12 & 9.38 & 2.00 & 8.00 & 15.00 & 26.00 & 66.00 & 6.00 \\
\hline & & ICU & 10.50 & 14.14 & 11.50 & 7.00 & 15.00 & 30.50 & 41.25 & 58.00 & 8.00 \\
\hline & \multirow{2}{*}{35,40} & non-ICU & 5.00 & 8.88 & 12.84 & 3.00 & 10.00 & 19.00 & 29.00 & 165.00 & 7.00 \\
\hline & & $\mathrm{ICU}$ & 13.00 & 17.76 & 17.42 & 9.00 & 21.75 & 36.00 & 39.95 & 129.00 & 12.75 \\
\hline & \multirow{2}{*}{40,45} & non-ICU & 6.00 & 9.17 & 11.02 & 4.00 & 10.00 & 19.00 & 28.00 & 143.00 & 6.00 \\
\hline & & $\mathrm{ICU}$ & 13.00 & 20.10 & 22.70 & 8.00 & 23.00 & 40.00 & 50.00 & 216.00 & 15.00 \\
\hline & \multirow{2}{*}{45,50} & non-ICU & 7.00 & 9.92 & 11.29 & 4.00 & 11.00 & 21.00 & 30.00 & 213.00 & 7.00 \\
\hline & & $\mathrm{ICU}$ & 14.00 & 21.54 & 21.60 & 9.00 & 26.75 & 46.00 & 61.00 & 193.00 & 17.75 \\
\hline & {$[50.55]$} & non-ICU & 8.00 & 10.86 & 11.88 & 5.00 & 12.00 & 23.00 & 32.00 & 132.00 & 7.00 \\
\hline & {$[00,00)$} & $\mathrm{ICU}$ & 18.00 & 23.31 & 22.43 & 11.00 & 29.00 & 43.00 & 54.50 & 202.00 & 18.00 \\
\hline & {$[55.66 \mathrm{~s}$} & non-ICU & 8.00 & 11.11 & 12.50 & 5.00 & 13.00 & 23.00 & 32.00 & 167.00 & 8.00 \\
\hline & {$[50,00)$} & ICU & 19.00 & 24.70 & 20.31 & 11.00 & 30.25 & 53.00 & 64.05 & 151.00 & 19.25 \\
\hline & & non-ICU & 8.00 & 12.26 & 13.80 & 5.00 & 14.00 & 26.00 & 37.00 & 239.00 & 9.00 \\
\hline & {$[60,65)$} & $\mathrm{ICU}$ & 19.00 & 25.09 & 21.32 & 11.00 & 33.00 & 52.00 & 66.00 & 180.00 & 22.00 \\
\hline & $(65,70)$ & non-ICU & 9.00 & 13.05 & 15.30 & 5.00 & 15.00 & 27.00 & 38.00 & 228.00 & 10.00 \\
\hline & {$[00,70)$} & $\mathrm{ICU}$ & 19.00 & 25.50 & 22.75 & 12.00 & 31.00 & 53.90 & 67.00 & 199.00 & 19.00 \\
\hline & 70 & non-ICU & 10.00 & 14.06 & 15.39 & 5.00 & 17.00 & 30.00 & 42.00 & 348.00 & 12.00 \\
\hline & {$[10$} & ICU & 20.00 & 26.46 & 21.94 & 12.00 & 34.00 & 56.00 & 72.00 & 168.00 & 22.00 \\
\hline & & non-ICU & 10.00 & 14.32 & 15.19 & 5.00 & 18.00 & 31.00 & 41.00 & 230.00 & 13.00 \\
\hline & {$[75,8$} & $\mathrm{ICU}$ & 19.00 & 25.79 & 23.40 & 11.00 & 31.00 & 58.50 & 80.25 & 168.00 & 20.00 \\
\hline & {$[80.150$} & non-ICU & 9.00 & 13.44 & 14.54 & 5.00 & 17.00 & 29.00 & 39.00 & 267.00 & 12.00 \\
\hline & {$[80,150)$} & $\mathrm{ICU}$ & 17.00 & 22.67 & 20.96 & 9.00 & 28.00 & 46.70 & 61.00 & 210.00 & 19.00 \\
\hline & Fem & non-ICU & 8.00 & 12.32 & 14.51 & 4.00 & 15.00 & 27.00 & 37.00 & 348.00 & 11.00 \\
\hline Gender & Female & ICU & 17.00 & 23.82 & 22.36 & 10.00 & 29.00 & 50.00 & 67.00 & 210.00 & 19.00 \\
\hline & Male & non-ICU & 9.00 & 12.74 & 14.09 & 5.00 & 16.00 & 27.00 & 38.00 & 277.00 & 11.00 \\
\hline & Male & $\mathrm{ICU}$ & 18.00 & 24.53 & 21.82 & 11.00 & 31.00 & 51.00 & 66.00 & 216.00 & 20.00 \\
\hline & & non-ICU & 7.00 & 10.35 & 11.55 & 4.00 & 13.00 & 21.00 & 29.00 & 178.00 & 9.00 \\
\hline & ejo & ICU & 19.00 & 23.87 & 19.52 & 12.00 & 29.25 & 48.00 & 58.25 & 126.00 & 17.25 \\
\hline & & non-ICU & 8.00 & 13.12 & 16.93 & 4.00 & 14.00 & 28.20 & 44.00 & 163.00 & 10.00 \\
\hline & Algarve & $\mathrm{ICU}$ & 17.00 & 22.83 & 20.86 & 11.50 & 27.00 & 42.80 & 57.80 & 216.00 & 15.50 \\
\hline $\mathrm{B}_{2}$ & Cen $>$ & non-ICU & 9.00 & 12.88 & 12.15 & 5.00 & 16.00 & 26.00 & 36.00 & 135.00 & 11.00 \\
\hline Keg1on & Centro & ICU & 19.00 & 23.50 & 16.28 & 12.00 & 31.00 & 44.00 & 55.10 & 113.00 & 19.00 \\
\hline & $\mathrm{L}$ & non-ICU & 9.00 & 13.28 & 15.03 & 4.00 & 17.00 & 29.00 & 40.00 & 348.00 & 13.00 \\
\hline & LV I & $\mathrm{ICU}$ & 18.00 & 24.56 & 21.92 & 11.00 & 31.00 & 51.50 & 66.00 & 210.00 & 20.00 \\
\hline & Norte & non-ICU & 8.00 & 11.77 & 14.31 & 4.00 & 14.00 & 26.00 & 36.00 & 277.00 & 10.00 \\
\hline & Norle & ICU & 17.00 & 24.44 & 23.56 & 10.00 & 31.00 & 54.00 & 70.65 & 202.00 & 21.00 \\
\hline
\end{tabular}

Table 13: Summary statistics of the TuD, by type of hospitalisation (non-ICU and ICU), month of discharge, age group, gender and region.

\begin{tabular}{|c|c|c|c|c|c|c|c|c|c|c|c|}
\hline Variable & Group & Local & median & mean & $\mathrm{sd}$ & $25 \%$ & $75 \%$ & $90 \%$ & $95 \%$ & $\operatorname{Max}$ & IQR \\
\hline \multirow{20}{*}{ Month } & \multirow{2}{*}{ 2020-03 } & non-ICU & 3.00 & 4.59 & 4.22 & 2.00 & 6.00 & 9.00 & 11.40 & 24.00 & 4.00 \\
\hline & & $\mathrm{ICU}$ & 6.50 & 7.89 & 6.61 & 2.00 & 11.25 & 16.60 & 19.30 & 26.00 & 9.25 \\
\hline & \multirow{2}{*}{ 2020-04 } & non-ICU & 7.00 & 9.43 & 8.32 & 3.00 & 13.00 & 21.00 & 25.30 & 49.00 & 10.00 \\
\hline & & $\mathrm{ICU}$ & 12.00 & 14.24 & 9.83 & 7.00 & 22.00 & 29.80 & 32.90 & 38.00 & 15.00 \\
\hline & \multirow{2}{*}{$2020-05$} & non-ICU & 12.00 & 18.06 & 16.78 & 6.00 & 25.25 & 46.00 & 52.00 & 75.00 & 19.25 \\
\hline & & ICU & 24.50 & 28.77 & 18.05 & 18.75 & 35.25 & 49.70 & 62.40 & 80.00 & 16.50 \\
\hline & \multirow{2}{*}{$2020-06$} & non-ICU & 8.00 & 15.22 & 18.08 & 5.00 & 18.00 & 38.20 & 50.10 & 98.00 & 13.00 \\
\hline & & ICU & 26.00 & 32.21 & 29.02 & 10.00 & 43.00 & 75.60 & 91.00 & 101.00 & 33.00 \\
\hline & \multirow{2}{*}{$2020-07$} & non-ICU & 8.00 & 15.46 & 19.48 & 4.50 & 18.50 & 33.20 & 44.10 & 135.00 & 14.00 \\
\hline & & $\mathrm{ICU}$ & 12.00 & 24.36 & 32.26 & 6.00 & 24.75 & 61.40 & 110.20 & 139.00 & 18.75 \\
\hline & \multirow{2}{*}{ 2020-08 } & non-ICU & 11.50 & 17.62 & 17.88 & 5.00 & 22.50 & 39.50 & 61.00 & 90.00 & 17.50 \\
\hline & & $\mathrm{ICU}$ & 15.50 & 28.06 & 35.07 & 9.25 & 29.00 & 56.50 & 73.65 & 151.00 & 19.75 \\
\hline & \multirow{2}{*}{ 2020-09 } & non-ICU & 8.00 & 11.34 & 12.33 & 4.00 & 14.00 & 21.30 & 37.10 & 85.00 & 10.00 \\
\hline & & $\mathrm{ICU}$ & 12.00 & 13.79 & 9.15 & 9.00 & 19.00 & 22.20 & 29.40 & 43.00 & 10.00 \\
\hline & \multirow{2}{*}{$2020-10$} & non-ICU & 7.00 & 10.45 & 11.91 & 3.00 & 13.00 & 22.00 & 31.60 & 90.00 & 10.00 \\
\hline & & ICU & 13.00 & 17.87 & 18.22 & 6.50 & 24.00 & 37.60 & 46.00 & 141.00 & 17.50 \\
\hline & \multirow{2}{*}{ 2020-11 } & non-ICU & 6.00 & 9.36 & 11.60 & 3.00 & 12.00 & 19.00 & 26.55 & 163.00 & 9.00 \\
\hline & & $\mathrm{ICU}$ & 13.00 & 15.89 & 13.61 & 7.00 & 21.00 & 31.00 & 39.35 & 92.00 & 14.00 \\
\hline & \multirow{2}{*}{$2020-12$} & non-ICU & 8.00 & 11.03 & 12.37 & 4.00 & 14.00 & 22.90 & 30.45 & 206.00 & 10.00 \\
\hline & & $\mathrm{ICU}$ & 17.00 & 19.01 & 12.10 & 10.00 & 26.25 & 35.00 & 40.25 & 82.00 & 16.25 \\
\hline
\end{tabular}


medRxiv preprint doi: https://doi.org/10.1101/2022.03.03.22271349; this version posted March 6, 2022. The copyright holder for this preprint (which was not certified by peer review) is the author/funder, who has granted medRxiv a license to display the preprint in perpetuity.

It is made available under a CC-BY-NC 4.0 International license .

\begin{tabular}{|c|c|c|c|c|c|c|c|c|c|c|c|}
\hline & \multirow{2}{*}{ 2021-01 } & non-ICU & 6.50 & 10.20 & 11.91 & 3.00 & 13.00 & 23.00 & 32.00 & 149.00 & 10.00 \\
\hline & & $\mathrm{ICU}$ & 13.00 & 17.46 & 15.79 & 8.00 & 21.75 & 37.00 & 51.75 & 98.00 & 13.75 \\
\hline & \multirow{2}{*}{ 2021-02 } & non-ICU & 8.00 & 10.87 & 10.43 & 4.00 & 14.00 & 24.00 & 31.00 & 106.00 & 10.00 \\
\hline & & $\mathrm{ICU}$ & 17.00 & 20.44 & 17.46 & 12.00 & 25.00 & 32.40 & 45.70 & 180.00 & 13.00 \\
\hline & \multirow{2}{*}{ 2021-03 } & non-ICU & 14.00 & 19.73 & 20.59 & 7.00 & 25.00 & 41.00 & 58.20 & 178.00 & 18.00 \\
\hline & & $\mathrm{ICU}$ & 26.00 & 27.50 & 17.49 & 17.00 & 36.00 & 49.00 & 56.00 & 134.00 & 19.00 \\
\hline & \multirow{2}{*}{ 2021-04 } & non-ICU & 31.00 & 37.34 & 30.14 & 17.00 & 43.50 & 80.40 & 84.80 & 142.00 & 26.50 \\
\hline & & ICU & 35.00 & 39.84 & 24.17 & 20.00 & 64.00 & 75.60 & 84.20 & 89.00 & 44.00 \\
\hline & \multirow{2}{*}{ 2021-05 } & non-ICU & 96.50 & 114.75 & 86.61 & 52.25 & 159.00 & 200.40 & 214.20 & 228.00 & 106.75 \\
\hline & & $\mathrm{ICU}$ & 73.00 & 84.70 & 49.85 & 46.25 & 105.75 & 128.80 & 163.90 & 199.00 & 59.50 \\
\hline \multirow{34}{*}{$\begin{array}{l}\text { Age } \\
\text { Groups }\end{array}$} & \multirow{2}{*}{0,5} & non-ICU & 2.00 & 2.00 & - & 2.00 & 2.00 & 2.00 & 2.00 & 2.00 & 0.00 \\
\hline & & $\mathrm{ICU}$ & 18.00 & 18.00 & - & 18.00 & 18.00 & 18.00 & 18.00 & 18.00 & 0.00 \\
\hline & \multirow{2}{*}{5,10} & non-ICU & - & - & - & - & - & - & - & - & - \\
\hline & & $\mathrm{ICU}$ & - & - & - & - & - & - & - & - & - \\
\hline & \multirow{2}{*}{10,15} & non-ICU & - & - & - & - & - & - & - & - & - \\
\hline & & ICU & 1.00 & 1.00 & - & 1.00 & 1.00 & 1.00 & 1.00 & 1.00 & 0.00 \\
\hline & \multirow{2}{*}{15,20} & non-ICU & 48.00 & 48.00 & - & 48.00 & 48.00 & 48.00 & 48.00 & 48.00 & 0.00 \\
\hline & & ICU & - & - & - & - & - & - & - & - & - \\
\hline & \multirow{2}{*}{20,25} & non-ICU & 23.00 & 23.00 & - & 23.00 & 23.00 & 23.00 & 23.00 & 23.00 & 0.00 \\
\hline & & $\mathrm{ICU}$ & - & - & - & - & - & - & - & - & - \\
\hline & \multirow{2}{*}{25,30} & non-ICU & 6.00 & 14.20 & 23.48 & 2.00 & 6.00 & 36.00 & 46.00 & 56.00 & 4.00 \\
\hline & & ICU & 30.00 & 30.00 & - & 30.00 & 30.00 & 30.00 & 30.00 & 30.00 & 0.00 \\
\hline & \multirow{2}{*}{30,35} & non-ICU & 6.50 & 10.75 & 11.66 & 3.50 & 13.50 & 21.60 & 29.30 & 37.00 & 10.00 \\
\hline & & ICU & 7.00 & 8.29 & 4.27 & 6.00 & 11.50 & 13.40 & 13.70 & 14.00 & 5.50 \\
\hline & \multirow{2}{*}{35,40} & non-ICU & 6.00 & 15.59 & 23.32 & 5.00 & 17.00 & 29.80 & 49.20 & 98.00 & 12.00 \\
\hline & & $\mathrm{ICU}$ & 17.00 & 24.83 & 32.34 & 7.50 & 23.50 & 40.30 & 77.55 & 121.00 & 16.00 \\
\hline & & non-ICU & 8.00 & 15.50 & 14.80 & 4.75 & 26.75 & 39.00 & 40.95 & 51.00 & 22.00 \\
\hline & {$[40,45)$} & $\mathrm{ICU}$ & 11.50 & 20.75 & 27.95 & 7.25 & 23.50 & 37.40 & 46.10 & 139.00 & 16.25 \\
\hline & & non-ICU & 9.50 & 14.62 & 15.81 & 3.75 & 21.00 & 29.30 & 45.45 & 83.00 & 17.25 \\
\hline & {$[45,50)$} & ICU & 16.00 & 26.24 & 29.27 & 8.00 & 30.00 & 61.80 & 78.60 & 142.00 & 22.00 \\
\hline & & non-ICU & 10.00 & 16.17 & 16.96 & 5.00 & 22.50 & 37.70 & 51.45 & 83.00 & 17.50 \\
\hline & {$[50,55)$} & ICU & 20.00 & 24.91 & 22.40 & 12.00 & 30.75 & 46.00 & 60.70 & 141.00 & 18.75 \\
\hline & {$[55,60)$} & non-ICU & 11.00 & 16.78 & 19.55 & 5.00 & 21.75 & 37.00 & 51.95 & 142.00 & 16.75 \\
\hline & {$[55,60)$} & ICU & 19.00 & 24.48 & 22.47 & 11.00 & 29.00 & 44.40 & 62.70 & 151.00 & 18.00 \\
\hline & {$[6065$} & non-ICU & 8.00 & 13.88 & 17.73 & 3.50 & 18.50 & 32.00 & 43.00 & 178.00 & 15.00 \\
\hline & {$[00,00)$} & $\mathrm{ICU}$ & 17.00 & 21.56 & 19.59 & 10.00 & 27.00 & 43.60 & 56.95 & 180.00 & 17.00 \\
\hline & & non-ICU & 9.00 & 13.79 & 14.88 & 4.00 & 19.00 & 31.00 & 43.80 & 99.00 & 15.00 \\
\hline & {$[65,70$} & ICU & 16.00 & 21.21 & 20.63 & 9.00 & 27.00 & 41.00 & 55.00 & 199.00 & 18.00 \\
\hline & $570.75)$ & non-ICU & 8.00 & 13.58 & 15.70 & 4.00 & 17.00 & 30.70 & 41.00 & 132.00 & 13.00 \\
\hline & {$[70,75)$} & $\mathrm{ICU}$ & 16.00 & 19.24 & 14.58 & 10.00 & 26.00 & 35.20 & 45.00 & 101.00 & 16.00 \\
\hline & & non-ICU & 8.00 & 11.53 & 12.21 & 4.00 & 15.00 & 25.00 & 33.45 & 149.00 & 11.00 \\
\hline & {$[75,80$} & ICU & 16.00 & 19.20 & 16.38 & 9.00 & 24.00 & 36.00 & 49.00 & 112.00 & 15.00 \\
\hline & & non-ICU & 7.00 & 10.09 & 11.68 & 3.00 & 13.00 & 22.00 & 29.00 & 228.00 & 10.00 \\
\hline & {$[80,150)$} & ICU & 12.00 & 15.77 & 14.07 & 7.00 & 20.00 & 32.00 & 43.00 & 115.00 & 13.00 \\
\hline & & non-ICU & 7.00 & 10.22 & 12.30 & 3.00 & 13.00 & 22.00 & 31.00 & 206.00 & 10.00 \\
\hline Condon & $\mathrm{F}$ & $\mathrm{ICU}$ & 15.00 & 18.99 & 18.87 & 8.00 & 24.00 & 37.00 & 53.00 & 180.00 & 16.00 \\
\hline Gender & & non-ICU & 8.00 & 11.74 & 13.19 & 4.00 & 15.00 & 25.00 & 34.00 & 228.00 & 11.00 \\
\hline & Male & $\mathrm{ICU}$ & 17.00 & 20.47 & 18.27 & 9.00 & 26.00 & 39.00 & 53.00 & 199.00 & 17.00 \\
\hline & & non-ICU & 5.00 & 7.83 & 10.97 & 3.00 & 10.00 & 16.00 & 22.25 & 178.00 & 7.00 \\
\hline & Ilentejo & $\mathrm{ICU}$ & 17.00 & 20.84 & 18.29 & 7.00 & 23.50 & 51.50 & 58.75 & 89.00 & 16.50 \\
\hline & & non-ICU & 8.00 & 13.94 & 20.79 & 4.00 & 15.00 & 28.80 & 41.80 & 163.00 & 11.00 \\
\hline & Algarve & $\mathrm{ICU}$ & 16.00 & 18.92 & 11.30 & 11.25 & 26.00 & 30.00 & 38.75 & 64.00 & 14.75 \\
\hline Rogion & & non-ICU & 7.00 & 10.51 & 10.97 & 4.00 & 13.00 & 23.00 & 29.00 & 135.00 & 9.00 \\
\hline Region & Centro & $\mathrm{ICU}$ & 16.00 & 18.50 & 13.15 & 10.00 & 24.25 & 34.00 & 40.45 & 96.00 & 14.25 \\
\hline & & non-ICU & 8.00 & 12.08 & 13.94 & 4.00 & 16.00 & 26.00 & 36.00 & 228.00 & 12.00 \\
\hline & LV T & ICU & 15.00 & 19.56 & 17.76 & 8.00 & 26.00 & 38.60 & 54.60 & 180.00 & 18.00 \\
\hline & & non-ICU & 7.00 & 10.29 & 11.59 & 3.00 & 13.00 & 22.00 & 32.00 & 163.00 & 10.00 \\
\hline & Norte & $\mathrm{ICU}$ & 16.00 & 21.19 & 21.40 & 8.00 & 27.00 & 43.00 & 59.50 & 199.00 & 19.00 \\
\hline
\end{tabular}


medRxiv preprint doi: https://doi.org/10.1101/2022.03.03.22271349; this version posted March 6, 2022. The copyright holder for this preprint (which was not certified by peer review) is the author/funder, who has granted medRxiv a license to display the preprint in perpetuity.

It is made available under a CC-BY-NC 4.0 International license .

COVID-19 Hospitalisation in Portugal, the first year: Results from hospital discharge data 31

\section{A.5. Additional plots}

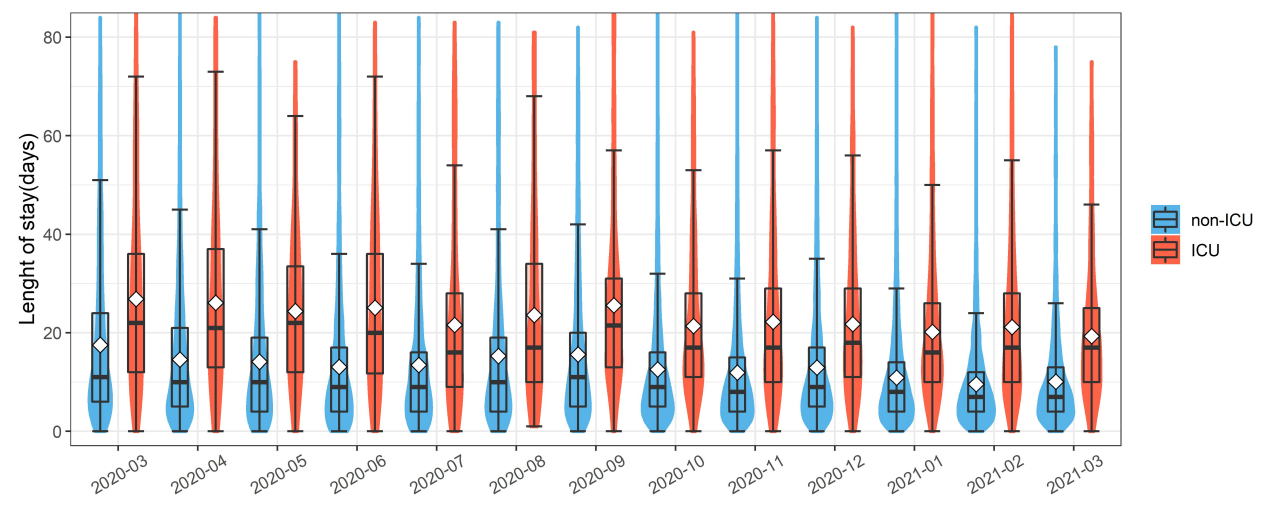

(a)

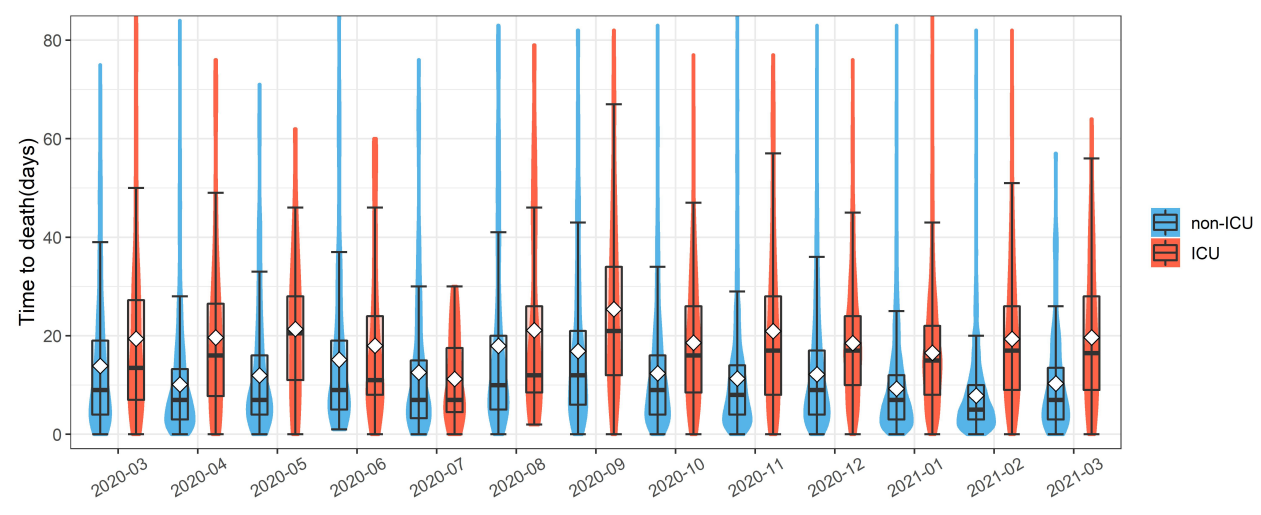

(b)

Figure 14: Violin/box plots of the (a)LoS and (b)TuD, by month and type of hospitalisation (white diamonds represent the mean). 
medRxiv preprint doi: https://doi.org/10.1101/2022.03.03.22271349; this version posted March 6, 2022. The copyright holder for this preprint (which was not certified by peer review) is the author/funder, who has granted medRxiv a license to display the preprint in perpetuity.

It is made available under a CC-BY-NC 4.0 International license .

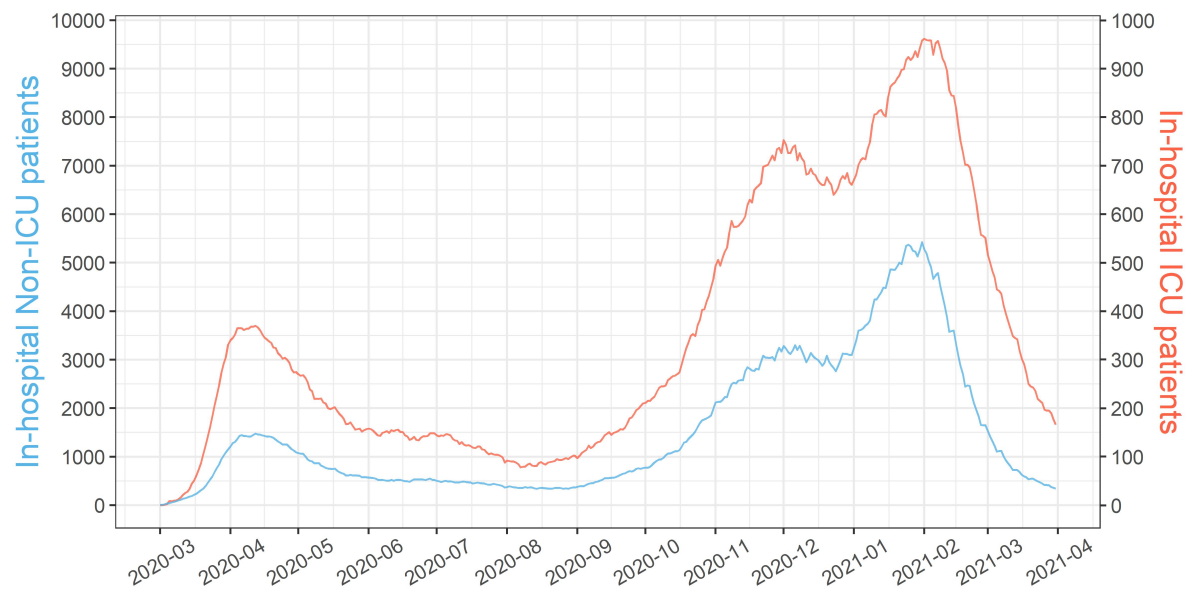

(a)

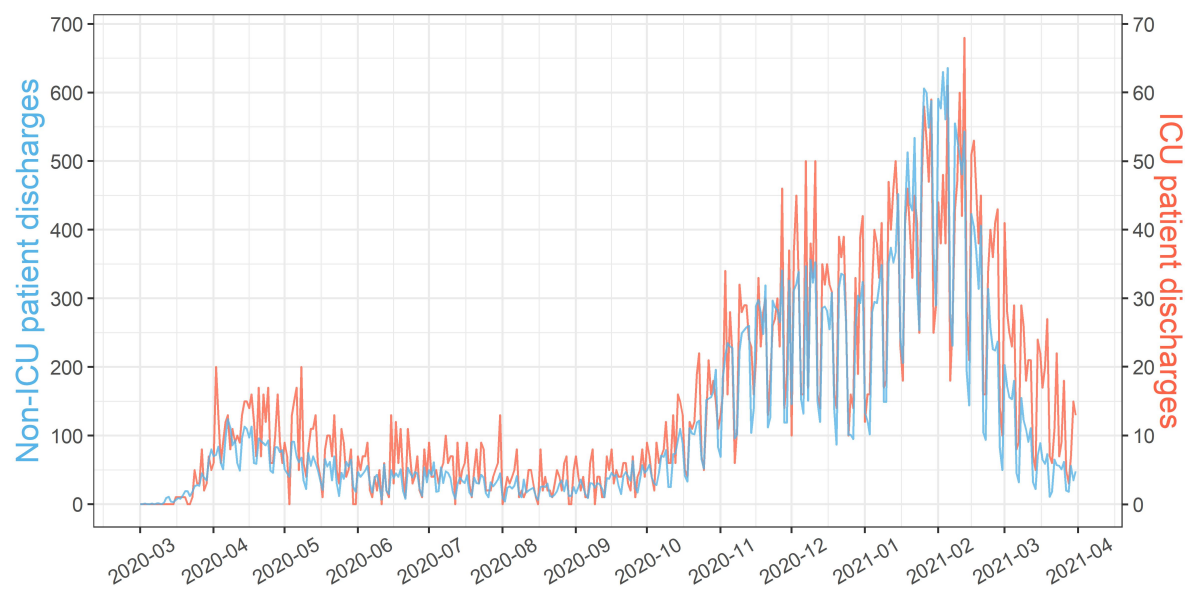

(b)

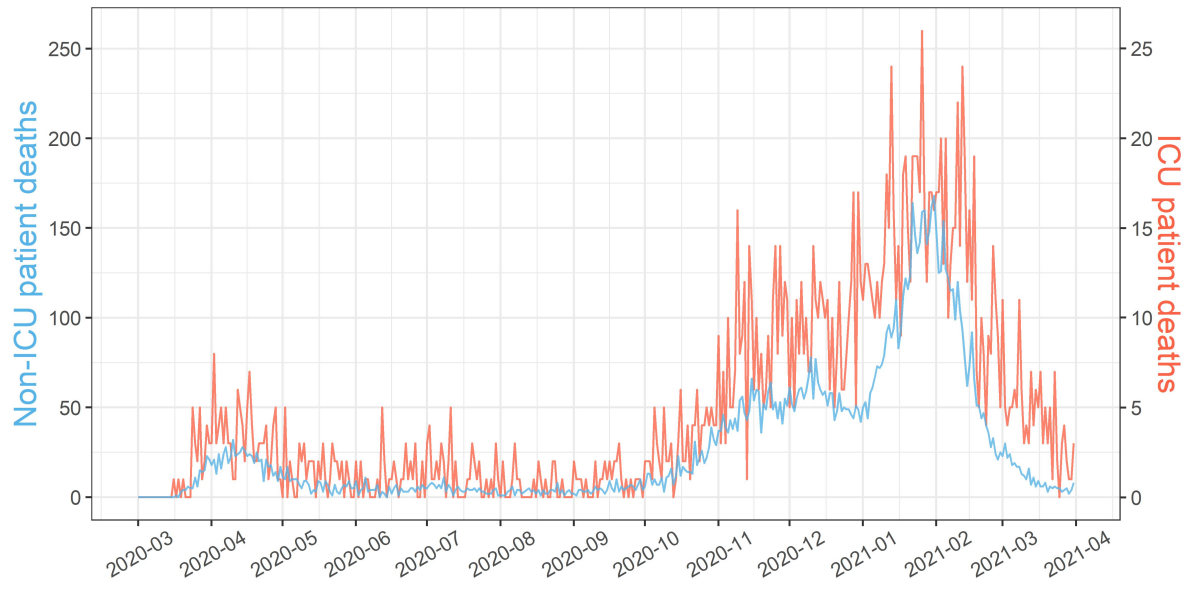

(c)

Figure 15: Evolution of patients (a)in-hospital, (b)discharged and (c)death with time, by type of hospitalization. 
medRxiv preprint doi: https://doi.org/10.1101/2022.03.03.22271349; this version posted March 6, 2022. The copyright holder for this preprint (which was not certified by peer review) is the author/funder, who has granted medRxiv a license to display the preprint in perpetuity.

It is made available under a CC-BY-NC 4.0 International license .

COVID-19 Hospitalisation in Portugal, the first year: Results from hospital discharge data 33

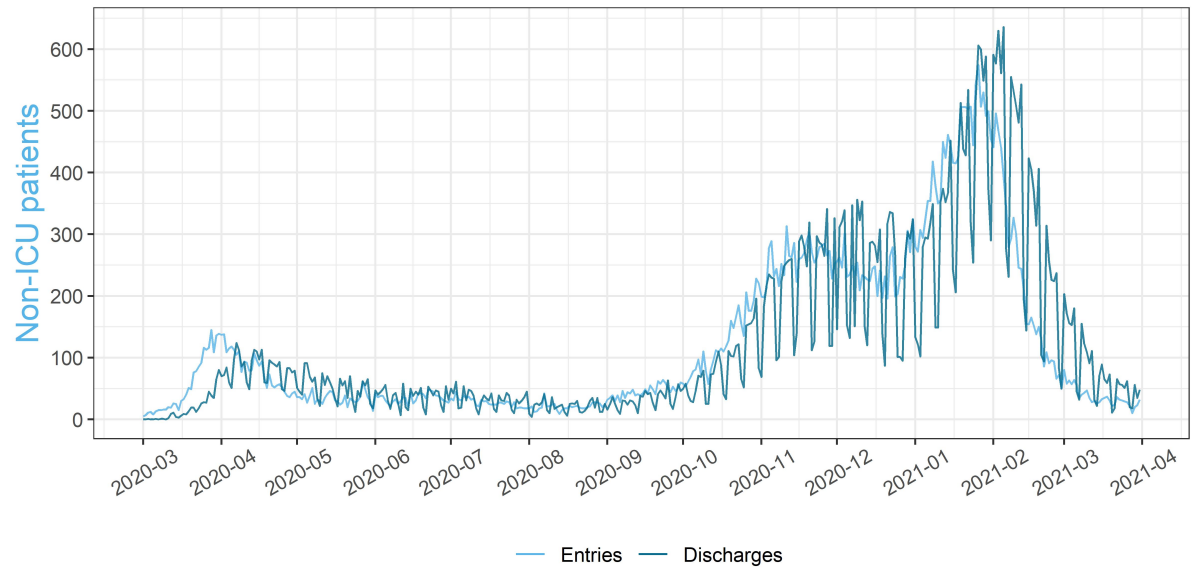

(a)

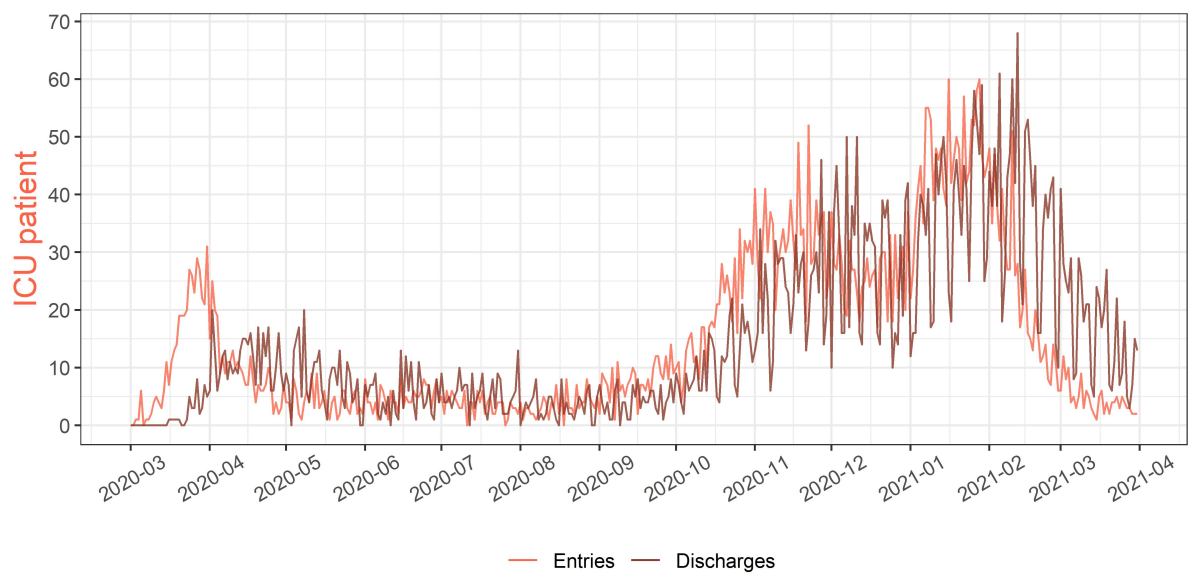

(b)

Figure 16: Comparing entries and exits by time, for (a)non-ICU and (b)ICU patients. 
medRxiv preprint doi: https://doi.org/10.1101/2022.03.03.22271349; this version posted March 6, 2022. The copyright holder for this preprint (which was not certified by peer review) is the author/funder, who has granted medRxiv a license to display the preprint in perpetuity.

It is made available under a CC-BY-NC 4.0 International license .

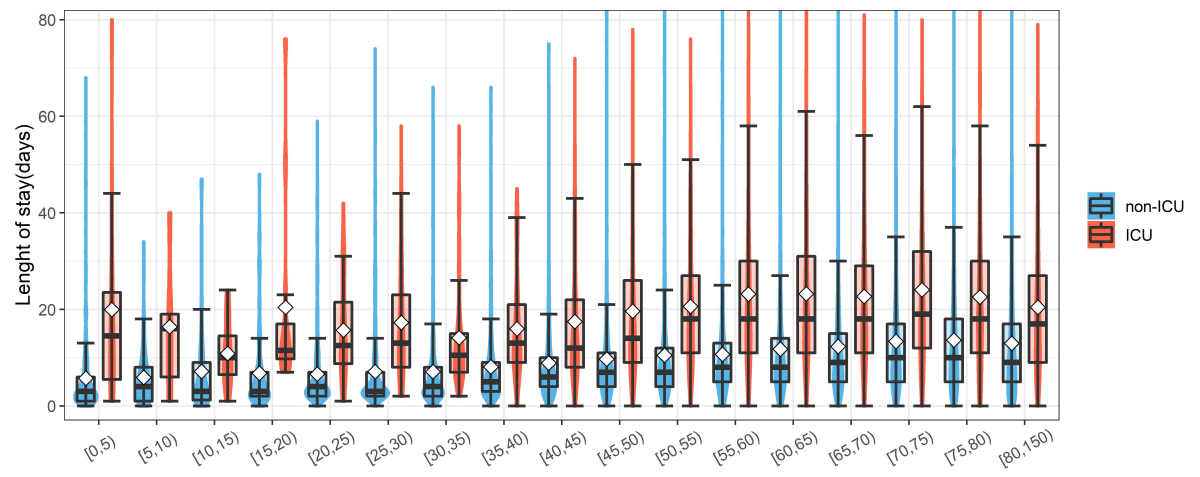

(a)

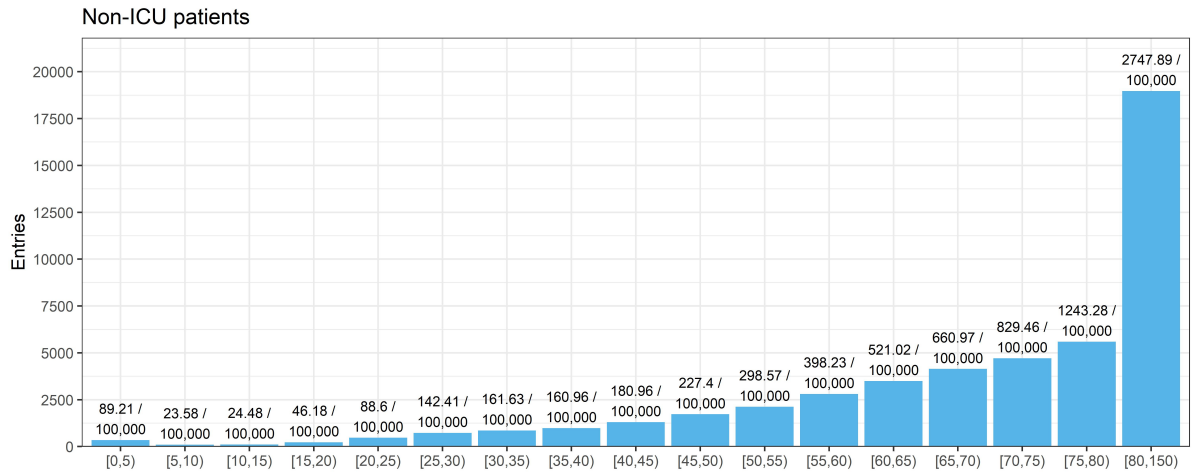

(b)

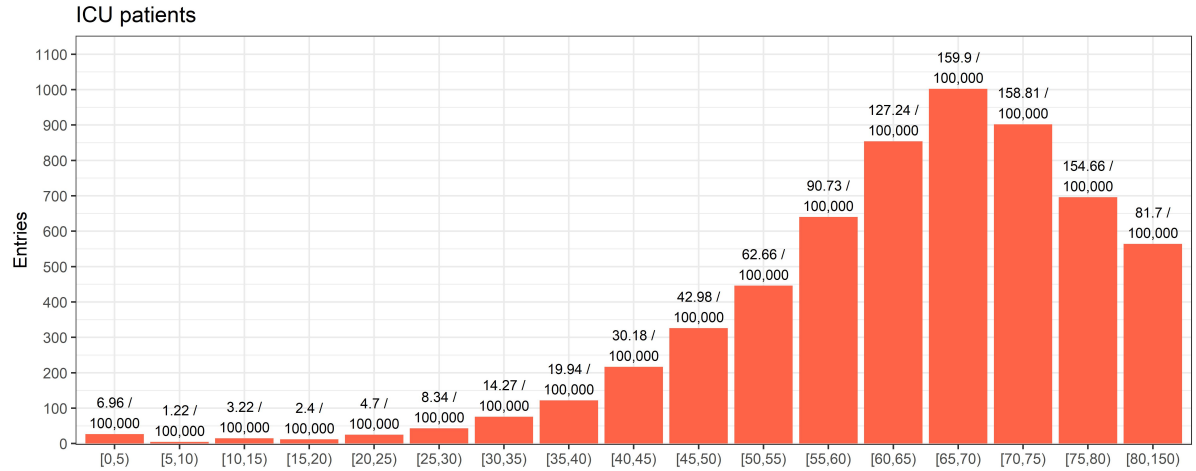

(c)

Figure 17: Characterization of the age groups. (a)Violin/box plot of the LoS by age groups (white diamonds represent the mean). Histograms of the number of entries, by age group, for (b)non-ICU and (c)ICU patients 
medRxiv preprint doi: https://doi.org/10.1101/2022.03.03.22271349; this version posted March 6, 2022. The copyright holder for this preprint (which was not certified by peer review) is the author/funder, who has granted medRxiv a license to display the preprint in perpetuity.

It is made available under a CC-BY-NC 4.0 International license .

COVID-19 Hospitalisation in Portugal, the first year: Results from hospital discharge data 35

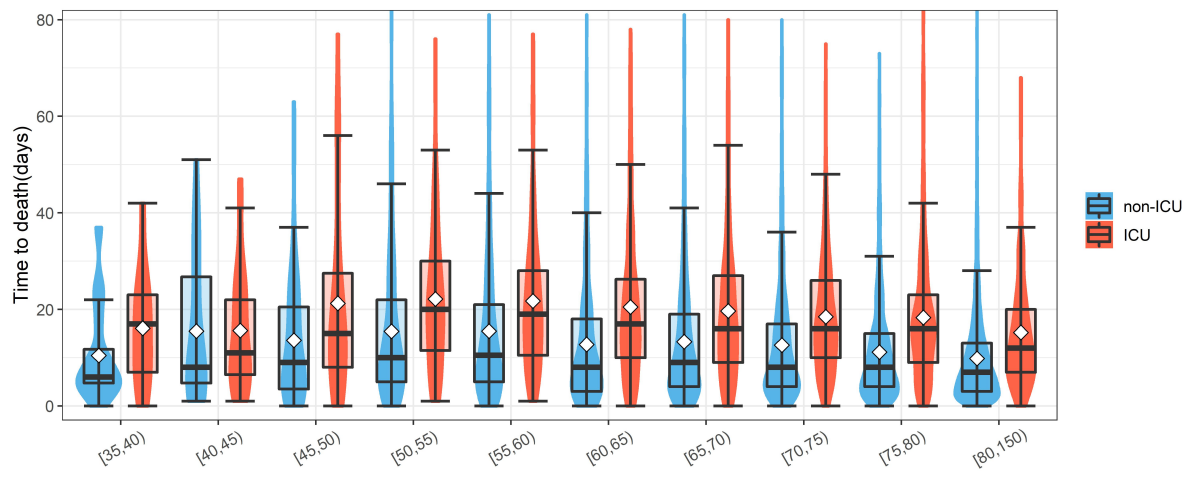

(a)

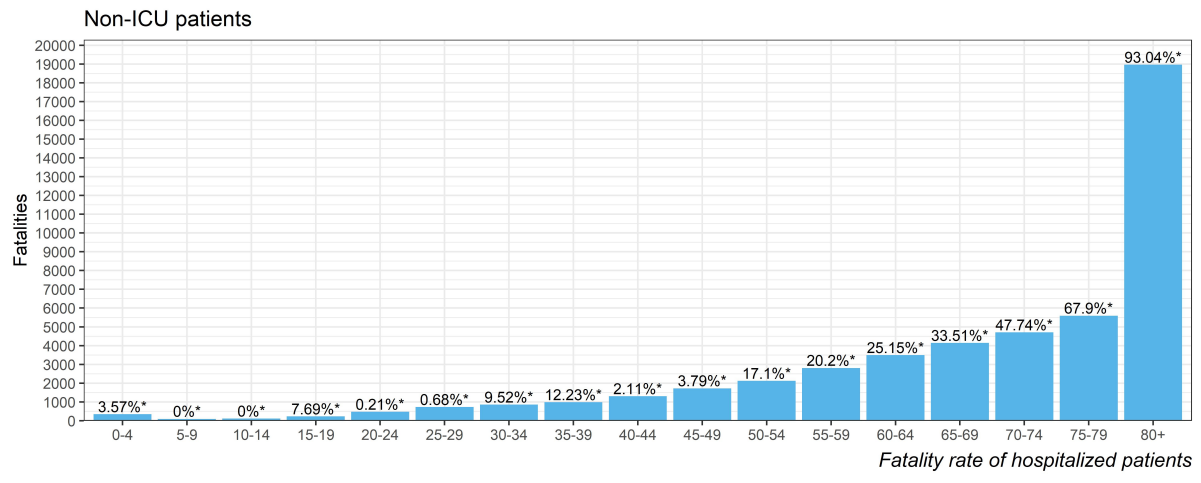

(b)

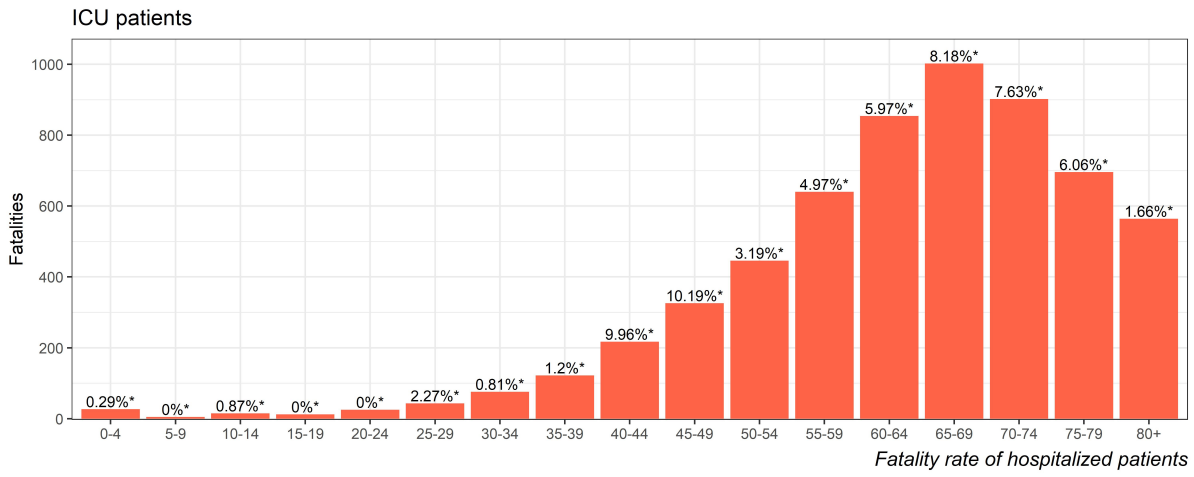

(c)

Figure 18: (a)Violin/box plot of the TuD by age groups (white diamonds represent the mean). Histogram of the fatalities, by age group, of (b)non-ICU and (c)ICU patients 
medRxiv preprint doi: https://doi.org/10.1101/2022.03.03.22271349; this version posted March 6, 2022. The copyright holder for this preprint (which was not certified by peer review) is the author/funder, who has granted medRxiv a license to display the preprint in perpetuity.

It is made available under a CC-BY-NC 4.0 International license .

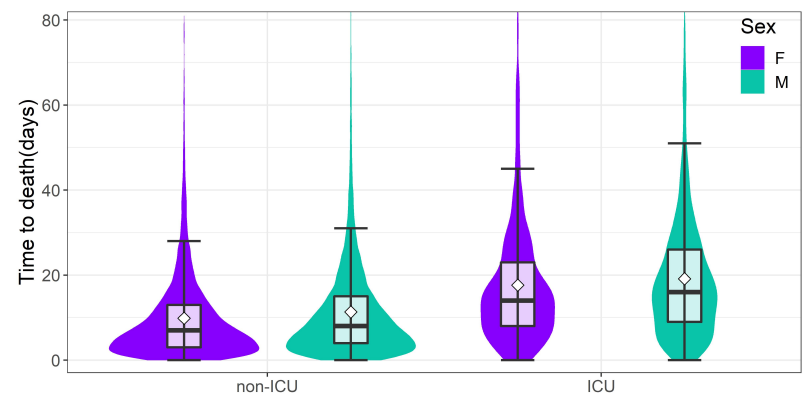

Figure 19: Violin/box plot of the TuD by gender and type of hospitalisation (white diamonds represent the mean).

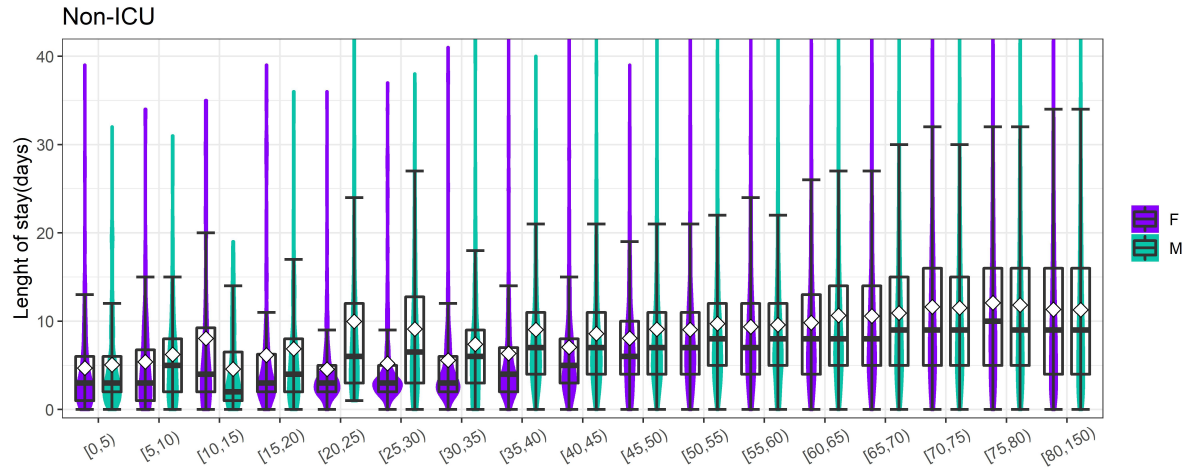

(a)

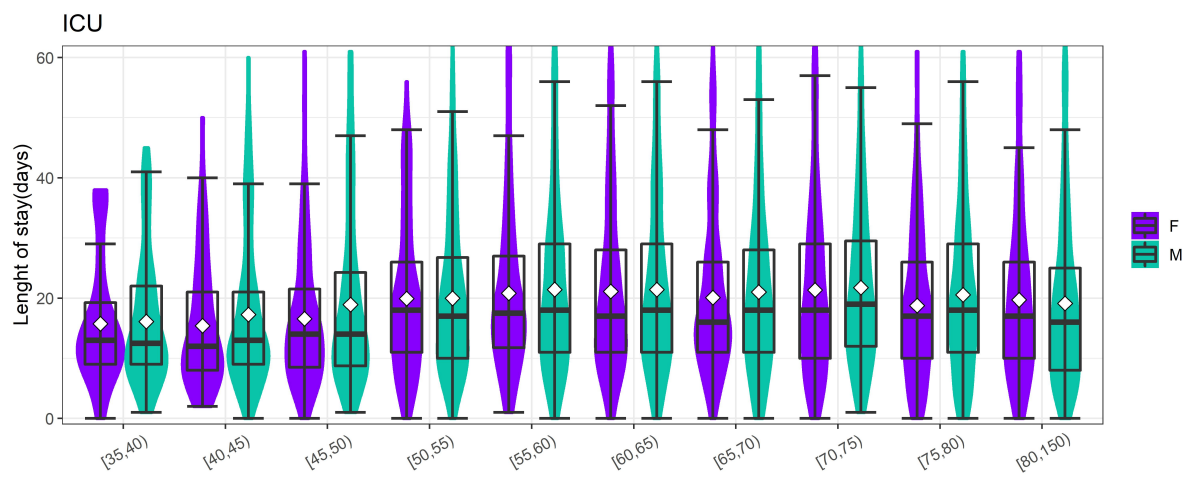

(b)

Figure 20: Violin/box plot of the LoS by gender and type of hospitalisation (white diamonds represent the mean). 
medRxiv preprint doi: https://doi.org/10.1101/2022.03.03.22271349; this version posted March 6, 2022. The copyright holder for this preprint (which was not certified by peer review) is the author/funder, who has granted medRxiv a license to display the preprint in perpetuity.

It is made available under a CC-BY-NC 4.0 International license.

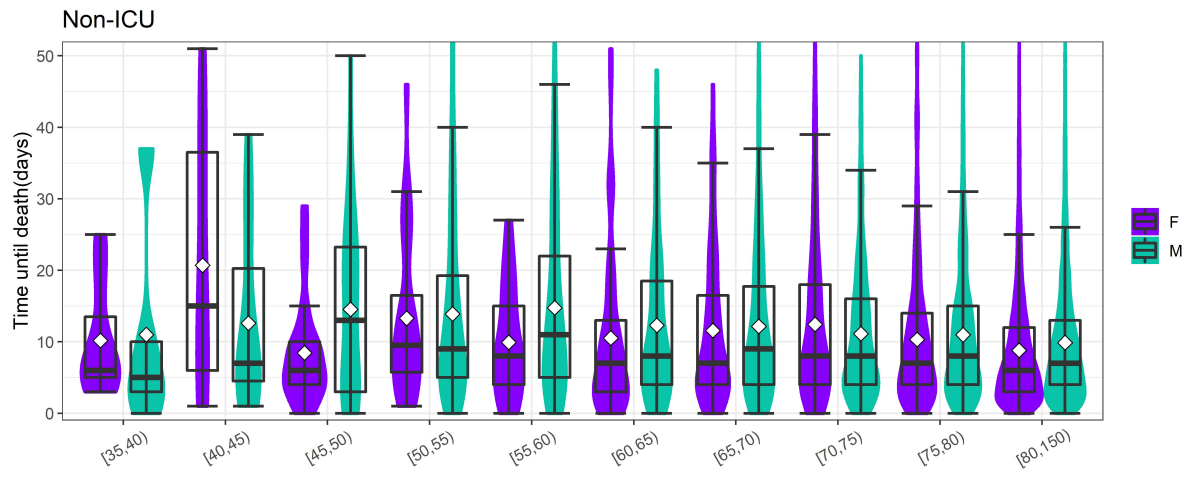

(a)

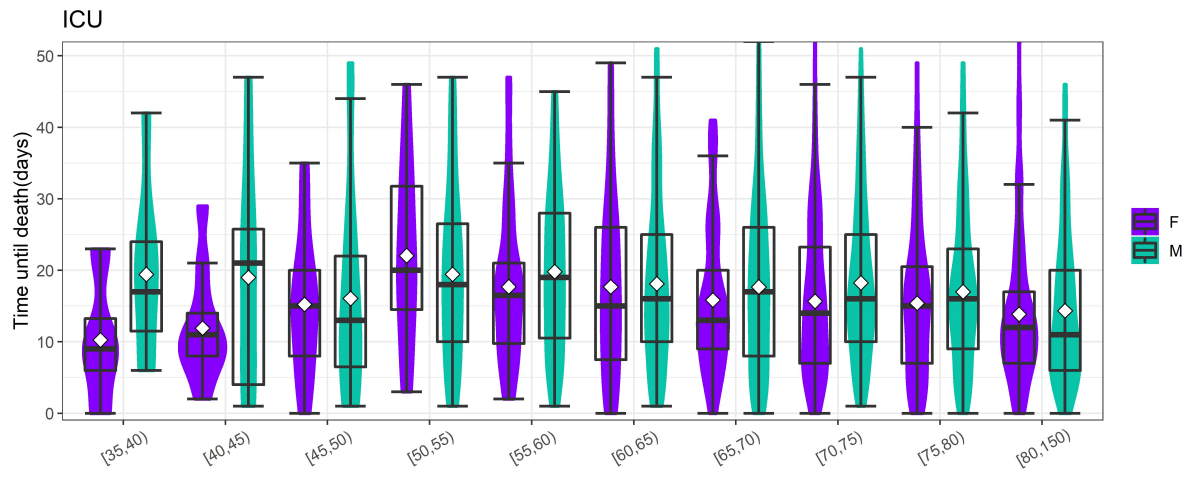

(b)

Figure 21: Violin/box plot of the TuD by gender and type of hospitalisation (white diamonds represent the mean). 
medRxiv preprint doi: https://doi.org/10.1101/2022.03.03.22271349; this version posted March 6, 2022. The copyright holder for this preprint (which was not certified by peer review) is the author/funder, who has granted medRxiv a license to display the preprint in perpetuity.

It is made available under a CC-BY-NC 4.0 International license .

João F. Pereira

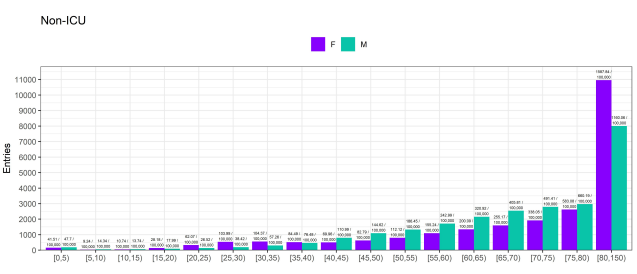

(a)

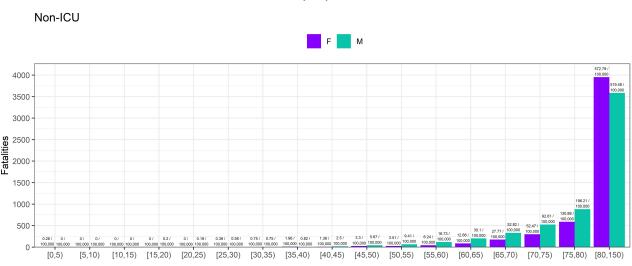

(c)

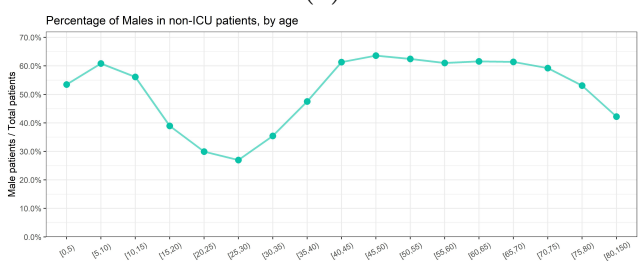

(e)

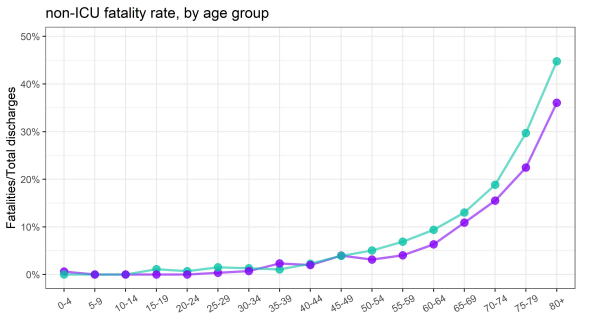

(g)

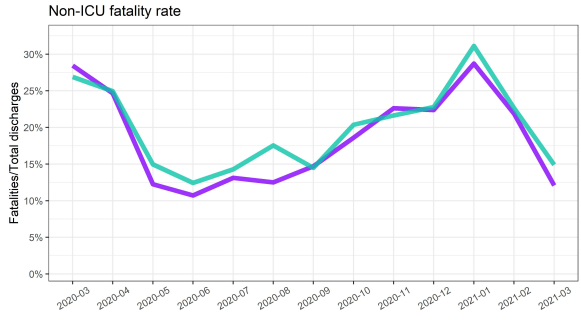

(i)
IcU

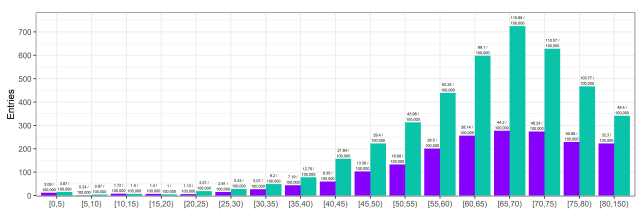

(b)

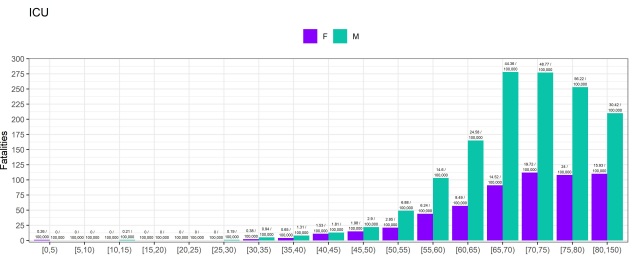

(d)

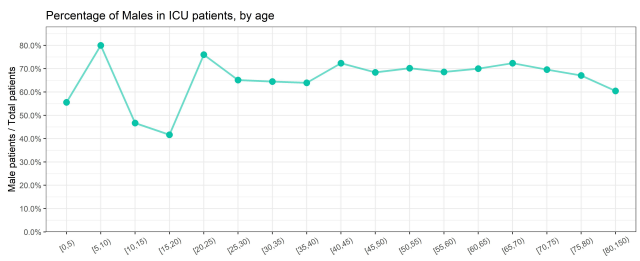

(f)

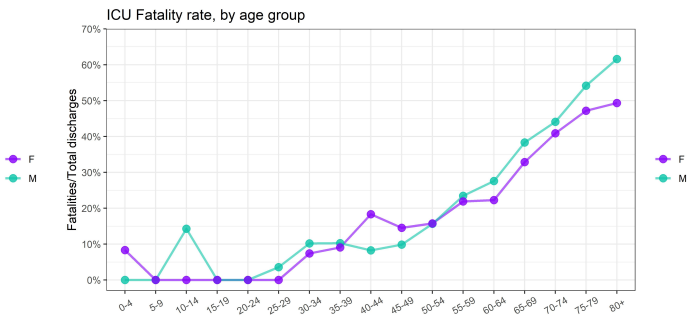

(h)

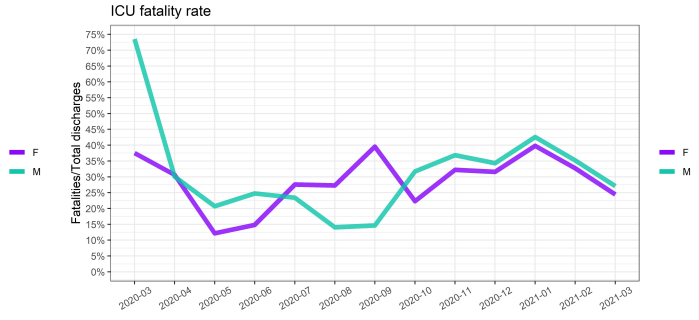

(j)

Figure 22: (a,b,c,d)Histograms with entries and fatalities for ICU and non-ICU patients. Linegraphs of fatalities rates by group for (e)non-ICU and (f)ICU patients. Percentage of males in (g)non-ICU and (h)ICU patients, for age group. Fatality rate over time for (i)non-ICU and (j)ICU. 
medRxiv preprint doi: https://doi.org/10.1101/2022.03.03.22271349; this version posted March 6, 2022. The copyright holder for this preprint (which was not certified by peer review) is the author/funder, who has granted medRxiv a license to display the preprint in perpetuity.

It is made available under a CC-BY-NC 4.0 International license .

COVID-19 Hospitalisation in Portugal, the first year: Results from hospital discharge data 39

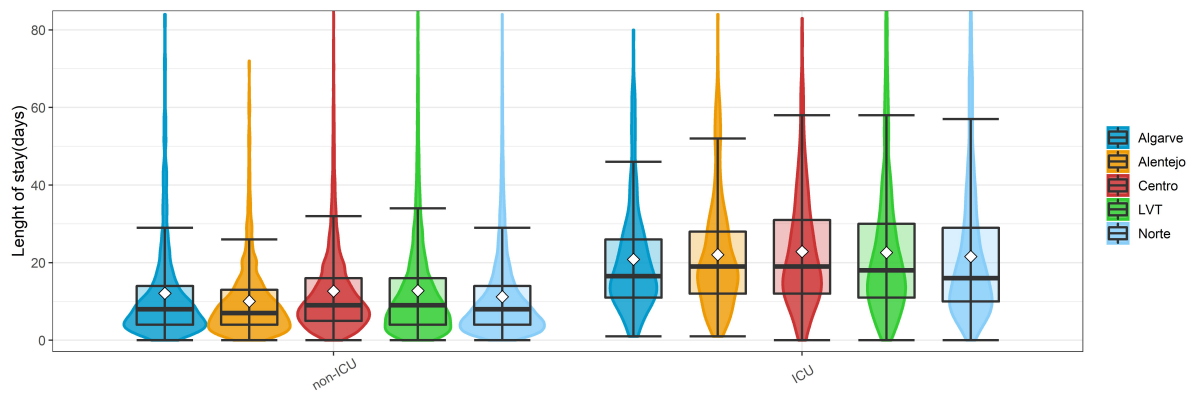

(a)

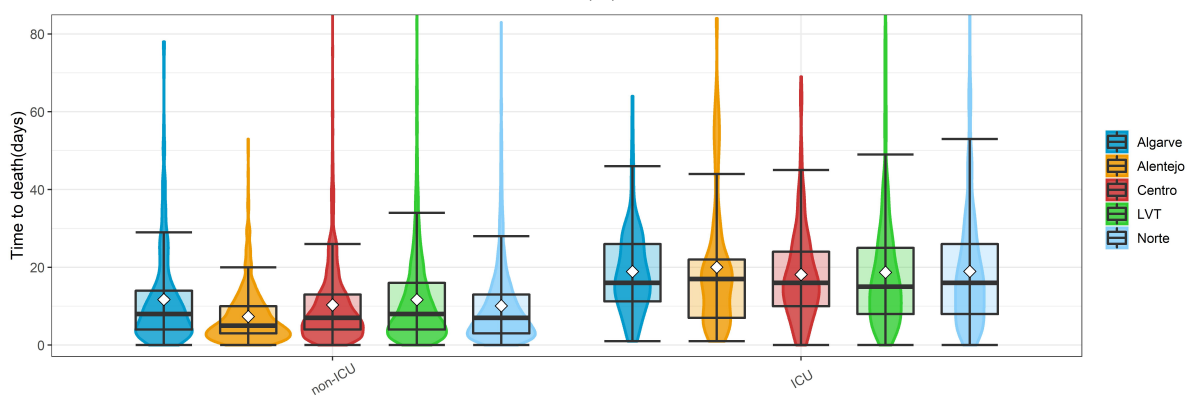

(b)

Figure 23: Violin/box plots of (a)LoS and (b)TuD by region (white diamonds represent the mean).

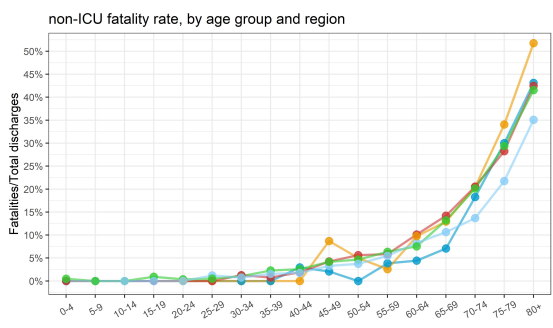

(a)

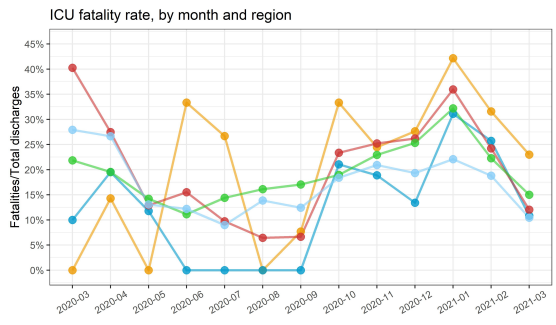

(c)

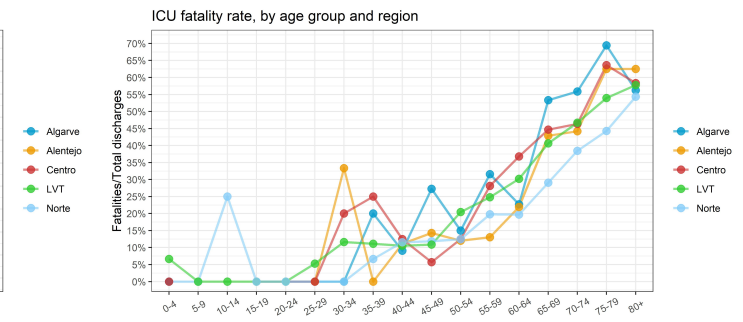

(b)
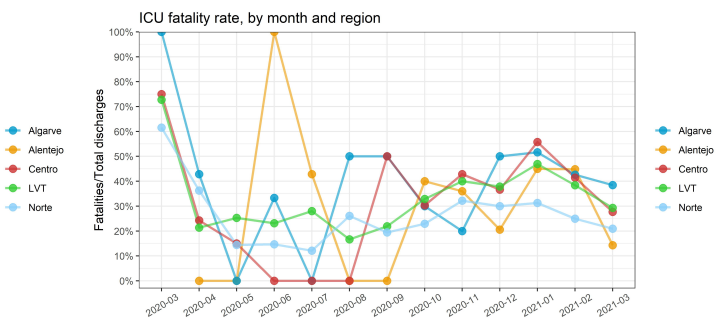

(d)

Figure 24: Linegraphs of fatalities rates by age group and region for (a) nonICU(a) and (b)ICU patients. Fatality rate by region and over time for (c)nonICU and (d)ICU (white diamonds represent the mean). 


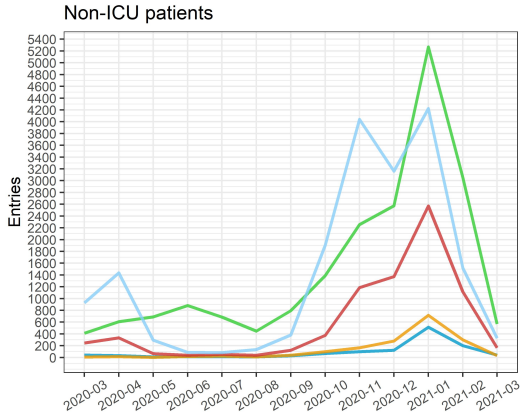

(a)

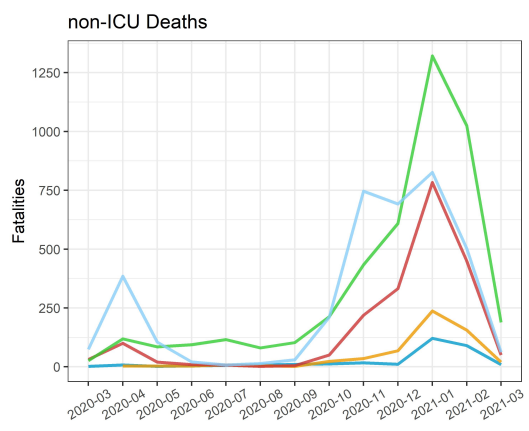

(c)
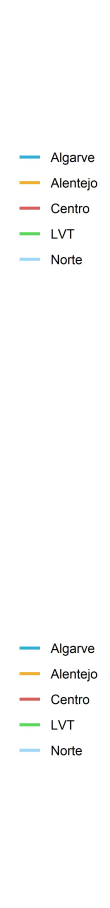

$$
\text { 造 }
$$

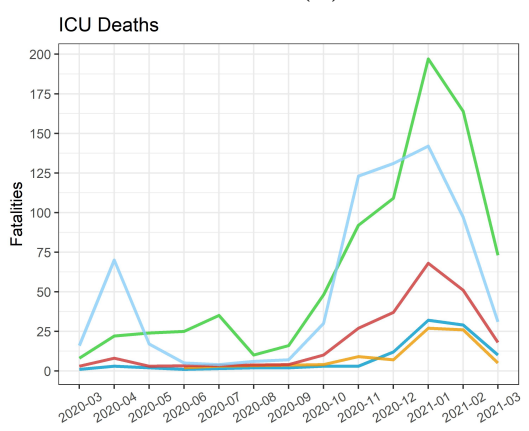

(d)

Figure 25: Linegraphs of entries by region for (a)non-ICU and (b)ICU patients entries, and fatalities for (c)non-ICU and (d)ICU patients fatalities

\section{A.6. Distribution fitting}

\begin{tabular}{c|c|c} 
Local & Hosp & ICU \\
\hline min & 1 & 1 \\
max & 348 & 216 \\
median & 9 & 18 \\
mean & 12.81596 & 24.43704 \\
estimated sd & 14.33082 & 21.97512 \\
estimated skewness & 4.475019 & 2.608978 \\
estimated kurtosis & 45.76527 & 13.74304
\end{tabular}

Table 14: LoS summary statistics for the Cullen and Frey graph (Figure 11). 
medRxiv preprint doi: https://doi.org/10.1101/2022.03.03.22271349; this version posted March 6, 2022. The copyright holder for this preprint (which was not certified by peer review) is the author/funder, who has granted medRxiv a license to display the preprint in perpetuity.

It is made available under a CC-BY-NC 4.0 International license .

COVID-19 Hospitalisation in Portugal, the first year: Results from hospital discharge data 41

\begin{tabular}{|cc|cc|}
\cline { 3 - 4 } \multicolumn{1}{c}{ LoS } & & non-ICU & ICU \\
\hline \multirow{2}{*}{ gamma } & shape & 1.3009479 & 1.236824 \\
& rate & 0.1015242 & 0.05061267 \\
\hline \multirow{2}{*}{ log-normal } & mean log & 2.119463 & 2.8582927 \\
& sd log & 0.9495999 & 0.8655452 \\
\hline \multirow{2}{*}{ Weibull } & shape & 1.263677 & 1.253865 \\
& scale & 13.09343 & 26.429118 \\
\hline \multirow{2}{*}{ gamma ADL } & shape & 1.5623940 & 1.236824 \\
& rate & 0.1403541 & 0.05061267 \\
\hline \multirow{2}{*}{ log-normal ADL } & mean log & 2.1465055 & 2.8986155 \\
& sd log & 0.9885536 & 0.8565485 \\
\hline
\end{tabular}

Table 15: Estimated LoS distribution parameters.

\begin{tabular}{c|ccc} 
& gamma & lognormal & Weibull \\
Goodness-of-fit statistics & & & \\
\hline Kolmogorov-Smirnov statistic & 0.07854276 & 0.05344594 & 0.07335166 \\
Cramer-von Mises statistic & 63.00402211 & 15.96330257 & 66.41153408 \\
Anderson-Darling statistic & 365.04226391 & 127.87010687 & 446.79678352 \\
& & & \\
Goodness-of-fit criteria & & & 337756.5 \\
\hline Akaike's Information Criterion & 336511.5 & 332306.2 & 337774.0 \\
Bayesian Information Criterion & 336529.0 & 332323.8 & \\
\hline \hline & gamma ADL & lognormal ADL & \\
Goodness-of-fit statistics & & & \\
\hline Kolmogorov-Smirnov statistic & 0.04724813 & 0.04920051 & \\
Cramer-von Mises statistic & 24.02657920 & 17.63190355 & \\
Anderson-Darling statistic & Inf & 145.71971535 & \\
Goodness-of-fit criteria & & & \\
Akaike's Information Criterion & 339100.5 & 332491.9 & \\
Bayesian Information Criterion & 339118.1 & 332509.4 &
\end{tabular}

Table 16: LoS goodness-of-fit statistics for non-ICU patients. 


\begin{tabular}{c|ccc} 
& gamma & lognormal & Weibull \\
Goodness-of-fit statistics & & & \\
\hline Kolmogorov-Smirnov statistic & 0.06457332 & 0.0566513 & 0.06895957 \\
Cramer-von Mises statistic & 2.8023735 & 1.76070045 & 8.34009006 \\
Anderson-Darling statistic & 19.9448961 & 12.46493868 & 50.56938674 \\
& & & \\
Goodness-of-fit criteria & & & 49350.59 \\
\hline Akaike's Information Criterion & 49117.16 & 49102.09 & 49363.97 \\
Bayesian Information Criterion & 49130.54 & 49115.47 & \\
\hline \hline & gamma ADL & lognormal ADL & \\
Goodness-of-fit statistics & & & \\
\hline Kolmogorov-Smirnov statistic & 0.04424102 & 0.03867471 & \\
Cramer-von Mises statistic & 1.97564933 & 1.69481544 & \\
Anderson-Darling statistic & 32.65844445 & 16.87600111 & \\
& & & \\
Goodness-of-fit criteria & & & \\
\hline Akaike's Information Criterion & 49360.57 & 49116.56 & \\
Bayesian Information Criterion & 49373.95 & 49129.94 &
\end{tabular}

Table 17: LoS goodness-of-fit statistics for ICU patients.

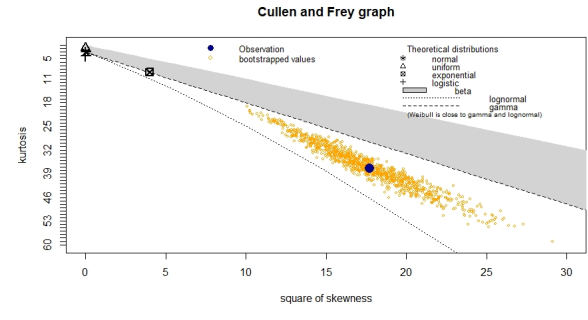

(a)

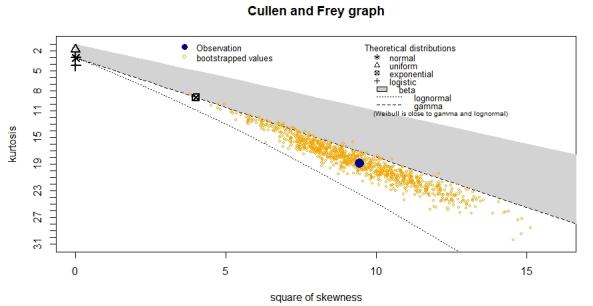

(b)

Figure 26: TuD Cullen and Frey graphs for (a)Non-ICU and (b)ICU patients.

\begin{tabular}{c|c|c} 
Local & Hosp & ICU \\
\hline min & 1 & 1 \\
max & 228 & 199 \\
median & 8 & 16 \\
mean & 11.33318 & 20.27451 \\
estimated sd & 11.33318 & 18.43436 \\
estimated skewness & 11.33318 & 3.072088 \\
estimated kurtosis & 37.3627 & 18.92779
\end{tabular}

Table 18: TuD Summary statistics for the Cullen and Frey graph (Figure 26. 
medRxiv preprint doi: https://doi.org/10.1101/2022.03.03.22271349; this version posted March 6, 2022. The copyright holder for this preprint (which was not certified by peer review) is the author/funder, who has granted medRxiv a license to display the preprint in perpetuity.

It is made available under a CC-BY-NC 4.0 International license .

COVID-19 Hospitalisation in Portugal, the first year: Results from hospital discharge data 43

\begin{tabular}{|cc|cc|}
\cline { 3 - 4 } \multicolumn{2}{c}{ TuD } & non-ICU & ICU \\
\hline \multirow{2}{*}{ gamma } & shape & 1.2314081 & 1.57990102 \\
& rate & 0.1087638 & 0.07792103 \\
\hline \multirow{2}{*}{ log-normal } & meanlog & 1.9684210 & 2.660706 \\
& sdlog & 0.9873343 & 0.898466 \\
\hline \multirow{2}{*}{ Weibull } & shape & 1.244128 & 1.246129 \\
& scale & 21.859276 & 21.898314 \\
\hline \multirow{2}{*}{ gamma ADL } & shape & 1.73385831 & 1.73596577 \\
& rate & 0.08887636 & 0.08882768 \\
\hline \multirow{2}{*}{ log-normal ADL } & meanlog & 2.734321 & 2.736472 \\
& sdlog & 0.939225 & 0.938759 \\
\hline
\end{tabular}

Table 19: Estimated TuD distribution parameters.

\begin{tabular}{c|ccc} 
& gamma & lognormal & Weibull \\
Goodness-of-fit statistics & & & \\
\hline Kolmogorov-Smirnov statistic & 0.06756849 & 0.05607134 & 0.07106338 \\
Cramer-von Mises statistic & 10.79585720 & 5.31072150 & 10.18207602 \\
Anderson-Darling statistic & 70.37506509 & 46.28643673 & 78.49461693 \\
& & & \\
Goodness-of-fit criteria & & & 73326.16 \\
\hline Akaike's Information Criterion & 73132.70 & 72288.43 & 73340.71 \\
Bayesian Information Criterion & 73147.26 & 72302.99 & \\
\hline \hline & gamma ADL & lognormal ADL & \\
Goodness-of-fit statistics & & & \\
\hline Kolmogorov-Smirnov statistic & 0.04833295 & 0.0518889 & \\
Cramer-von Mises statistic & 4.80060941 & 5.4628413 & \\
Anderson-Darling statistic & 66.41089597 & 52.02366989 & \\
Goodness-of-fit criteria & & & \\
\hline Akaike's Information Criterion & 73448.81 & 72412.75 & \\
Bayesian Information Criterion & 73463.37 & 72427.31 &
\end{tabular}

Table 20: TuD goodness-of-fit statistics for non-ICU patients. 


\begin{tabular}{c|ccc} 
& gamma & lognormal & Weibull \\
Goodness-of-fit statistics & & & \\
\hline Kolmogorov-Smirnov statistic & 0.04668797 & 0.08914086 & 0.05729949 \\
Cramer-von Mises statistic & 0.92583551 & 2.88870410 & 1.77441464 \\
Anderson-Darling statistic & 5.93558166 & 17.15111131 & 11.48495042 \\
& & & \\
Goodness-of-fit criteria & & & 15391.03 \\
\hline Akaike's Information Criterion & 15329.37 & 15401.71 & 15402.17 \\
Bayesian Information Criterion & 15340.51 & 15412.85 & \\
\hline \hline & gamma ADL & lognormal ADL & \\
Goodness-of-fit statistics & & & \\
\hline Kolmogorov-Smirnov statistic & 0.03759531 & 0.07105014 & \\
Cramer-von Mises statistic & 0.39364935 & 2.46654705 & \\
Anderson-Darling statistic & 3.98784875 & 18.87662199 & \\
& & & \\
Goodness-of-fit criteria & & & \\
\hline Akaike's Information Criterion & 15344.69 & 15421.03 & \\
Bayesian Information Criterion & 15355.83 & 15432.17 &
\end{tabular}

Table 21: TuD goodness-of-fit statistics for ICU patients.

\section{A.7. Links} link1: https://www.acss.min-saude.pt/wp-con
SNS-RH-ARS-n1-dados-a-junho-de-2016.pdf

- link2: https://www .ine.pt/xportal/xmain?xpid=INE\&xpgid=ine_indicadores\& ind0 corrCod $=0011166 \& x l a n g=p t$;

6 - link3: https://www.ine.pt/xportal/xmain?xpid=INE\&xpgid=ine_indicadores\& 